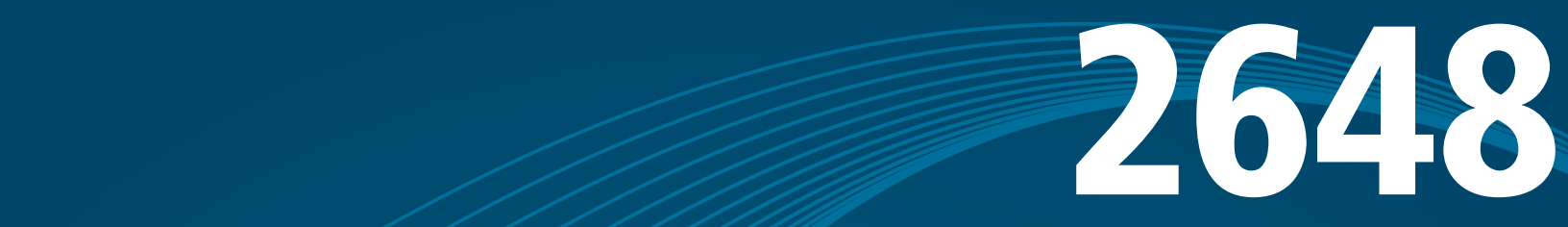

\title{
EMPRÉSTIMOS COM AMORTIZAÇÕES CONDICIONADAS À RENDA: CENÁRIOS DE FINANCIAMENTO DE ESTUDANTES DE ENSINO SUPERIOR NO BRASIL
}

Paulo Meyer Nascimento

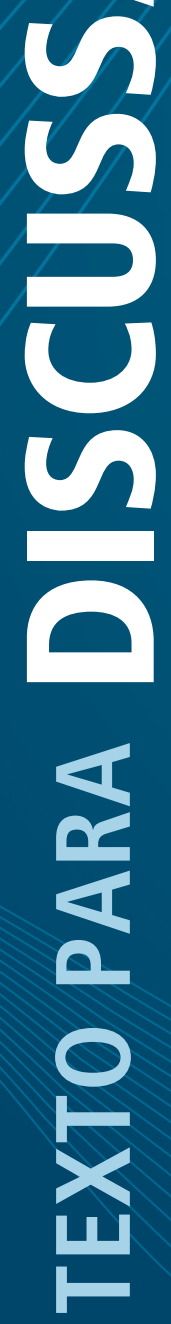





\section{TEXTO PARA DISCUSSÃO}

Brasília, abril de 2021

EMPRÉSTIMOS COM AMORTIZAÇÕES CONDICIONADAS À RENDA: CENÁRIOS DE FINANCIAMENTO DE ESTUDANTES DE ENSINO SUPERIOR NO BRASIL

Paulo Meyer Nascimento²

1. 0 autor agradece aos comentários de Herton Ellery Araújo e de João Alberto De Negri. Eventuais erros e omissões remanescentes são de inteira responsabilidade do autor.

2. Técnico de planejamento e pesquisa na Diretoria de Estudos e Políticas Sociais (Disoc) do Ipea. 


\section{Governo Federal \\ Ministério da Economia \\ Ministro Paulo Guedes}

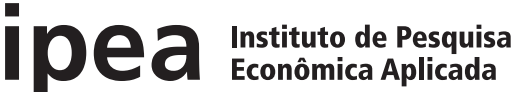

Fundação pública vinculada ao Ministério da Economia, o Ipea fornece suporte técnico e institucional às ações governamentais - possibilitando a formulação de inúmeras políticas públicas e programas de desenvolvimento brasileiros - e disponibiliza, para a sociedade, pesquisas e estudos realizados por seus técnicos.

\section{Presidente}

Carlos von Doellinger

Diretor de Desenvolvimento Institucional

Manoel Rodrigues Junior

Diretora de Estudos e Políticas do Estado, das Instituições e da Democracia

Flávia de Holanda Schmidt

\section{Diretor de Estudos e Políticas}

Macroeconômicas

José Ronaldo de Castro Souza Júnior

Diretor de Estudos e Políticas Regionais, Urbanas e Ambientais

Nilo Luiz Saccaro Júnior

Diretor de Estudos e Políticas Setoriais de Inovação e Infraestrutura

André Tortato Rauen

Diretora de Estudos e Políticas Sociais

Lenita Maria Turchi

Diretor de Estudos e Relações Econômicas

e Políticas Internacionais

Ivan Tiago Machado Oliveira

Assessor-chefe de Imprensa e Comunicação

André Reis Diniz

Ouvidoria: http://www.ipea.gov.br/ouvidoria

URL: http://www.ipea.gov.br

\section{Texto para Discussão}

Publicação seriada que divulga resultados de estudos e pesquisas em desenvolvimento pelo Ipea com o objetivo de fomentar o debate e oferecer subsídios à formulação e avaliação de políticas públicas.

(c) Instituto de Pesquisa Econômica Aplicada - ipea 2021

Texto para discussão / Instituto de Pesquisa Econômica Aplicada.- Brasília : Rio de Janeiro : Ipea , 1990-

ISSN 1415-4765

1.Brasil. 2.Aspectos Econômicos. 3.Aspectos Sociais. I. Instituto de Pesquisa Econômica Aplicada.

CDD 330.908

As publicações do Ipea estão disponíveis para download gratuito nos formatos PDF (todas) e EPUB (livros e periódicos). Acesse: http://www.ipea.gov.br/portal/publicacoes

As opiniões emitidas nesta publicação são de exclusiva e inteira responsabilidade dos autores, não exprimindo, necessariamente, o ponto de vista do Instituto de Pesquisa Econômica Aplicada ou do Ministério da Economia.

É permitida a reprodução deste texto e dos dados nele contidos, desde que citada a fonte. Reproduções para fins comerciais são proibidas.

JEL: H52; H81; G17; I22; I23; I28. 


\section{SUMÁRIO}

SINOPSE

ABSTRACT

1 INTRODUÇÃO

APÊNDICE A

APÊNDICE B

APÊNDICE C 



\section{SINOPSE}

Empréstimos com amortizações condicionadas à renda (ECRs) são um financiamento que otimiza as eficiências transacionais envolvidas no monopólio governamental de tributaçáo da renda pessoal. Protege o devedor contra períodos de baixa renda, pois as amortizaçôes variam de acordo com as flutuaçôes no seu rendimento ao longo da vida. Há décadas conjugam proteção social com sustentabilidade fiscal no financiamento de estudantes de ensino superior em número crescente de países. Este trabalho simula desenhos alternativos de ECR para financiamento estudantil no Brasil. Funçóes de cópula são aplicadas para captar padrôes de mobilidade na distribuição de rendimentos das pessoas com nível superior encontradas na Pesquisa Nacional por Amostra de Domicílio Contínua (PNAD Contínua) nos anos 2014 e 2015. Daí padrôes de amortização são simulados para hipotéticos desenhos de ECR. Os resultados permitem avaliar implicaçóes fiscais e distributivas relacionadas a alguns parâmetros, como taxas de juros, alíquotas e faixas de pagamento. Trata-se de uma avaliação ex ante de uma alternativa para o financiamento estudantil no Brasil perante as restriçóes fiscais por que passam os orçamentos públicos. Os melhores desenhos, em termos de acessibilidade para graduados e tamanho dos subsídios do contribuinte, envolvem ECRs com sobretaxas de 25\% adicionadas aos montantes iniciais dos empréstimos, taxas de juros no nível do custo de financiamento do governo cobradas depois de finalizado o curso, juro real zero durante a fase de estudos e para egressos com renda dentro da faixa de isençáo do Imposto de Renda Pessoa Física (IRPF) e taxas progressivas de pagamento alinhadas com as faixas de tributação da renda pessoal e equivalentes à metade das respectivas alíquotas para fins de IRPF.

Palavras-chave: ensino superior; financiamento; Brasil; empréstimos com amortizaçóes condicionadas à renda; crédito educacional.

\section{ABSTRACT}

Income contingent loans (ICLs) are a financial tool that optimizes the transactional efficiencies involved in the government monopoly in taxing personal income. It protects the borrowers against periods of low income, as instalments vary according to fluctuations in their incomes over the lifetime. For decades, ICLs have combined social protection with fiscal sustainability in financing higher education students in an increasing number of countries. This paper simulates alternative ICL designs for student financing in Brazil. Copula functions are applied to capture mobility patterns in the graduates' earnings distribution in the Continuous PNAD in years 2014 and 2015. Hence repayment patterns are simulated for hypothetical ICL designs. Results allow the evaluation 
of fiscal and distributional implications related to parameters such as interest rates and repayment rates and thresholds. This is an ex-ante evaluation of an alternative for higher education student financing in Brazil given the fiscal constraints of public budgets. The best designs, in terms of affordability for graduates and size of taxpayer's subsidies, involve ICLs with surcharges of $25 \%$ added to the initial loan amounts, interest rates at the level of government's cost of borrowing upon graduation and above initial tax threshold, and progressive repayment rates aligned with the personal income tax brackets and equivalent to half of the respective tax rates.

Keywords: higher education; financing; Brazil; income contingent loans; student loans. 


\section{INTRODUÇÃO}

Justificativas econômicas para financiamento público de cursos superiores partem da premissa de que os mercados privados sejam insuficientes para prover crédito educacional em um patamar socialmente ótimo, pois financiadores privados não teriam um bem para tomar em garantia em caso de inadimplência. Diante de crédito escasso e caro no mercado, e na ausência de suporte governamental, muitas pessoas não teriam condiçóes de investir em sua escolarização pós-secundária. Agrava-se o problema em países como o Brasil, que forma relativamente pouca gente em nível superior - comparaçóes internacionais reportadas no Education at a Glance (OCDE, 2020) mostram que 18\% da população adulta ${ }^{1}$ do Brasil concluiu curso superior, bem abaixo do patamar de $39 \%$ que corresponde à média observada nesse indicador para os países-membros da Organização para a Cooperação e Desenvolvimento Econômico (OCDE).

Em contrapartida, restriçóes fiscais e elevadas taxas médias de retorno privado enfatizam a necessidade de transferir parte dos custos da formação superior a quem dela se beneficia diretamente. São justamente essas as forças motrizes por trás de reformas mundo afora que introduzam ou expandam o financiamento compartilhado das atividades de ensino. Reformas nessa direção visam reduzir a dependência das instituiçôes de ensino dos orçamentos públicos e passam, entre outras coisas, pela cobrança de encargos educacionais (taxas e anuidades) em cursos de graduação e de pós-graduação. Trata-se de uma decisão política, mas, uma vez existente a cobrança, programas governamentais de financiamento estudantil ganham centralidade na agenda de políticas de educação superior e avaliaçóes ex ante podem ajudar na formulação de um sistema de financiamento estudantil que não onere em demasia nem quem estuda, nem o contribuinte.

Um dos caminhos mais discutidos na literatura internacional para um financiamento compartilhado mais eficaz e justo de cursos superiores passa pelos empréstimos com amortizaçóes condicionadas à renda (ECRs). ${ }^{2}$ Trata-se de um tipo de financiamento que protege o devedor contra períodos de baixa renda, já que as amortizaçóes variam de acordo com as flutuaçóes no seu rendimento ao longo da vida. Com uma implementação apropriada, os ECRs otimizam as eficiências transacionais envolvidas

1. Entenda-se por população adulta, nos relatórios da OCDE, o contingente de pessoas com idades entre 25 e 64 anos. 2. Ver, por exemplo, Chapman, Higgins e Stiglitz (2014). 
no monopólio governamental de tributação da renda pessoal para implementar amplos sistemas de empréstimos para financiar uma variedade de necessidades individuais. $\mathrm{O}$ financiamento de estudantes do ensino superior é apenas a modalidade de ECRs que já demonstra viabilidade prática, sendo realidade na Austrália (há três décadas) e na Inglaterra (há duas), com crescente adoção por outros países. ${ }^{3}$

Este trabalho simula desenhos alternativos de ECRs para financiar ensino superior no Brasil. O objetivo é discutir possibilidades para uma política federal de financiamento estudantil que, sem perder de vista a necessidade de expansáo do ensino superior com qualidade e justiça social, tanto avance na sustentabilidade financeira do Fundo de Financiamento Estudantil (Fies) - que existe para financiar matrículas em cursos pagos de graduação -, quanto na busca por um modelo de financiamento do ensino superior público que garanta gratuidade durante os estudos e, ao mesmo tempo, arrecade recursos adicionais para as próprias instituiçôes públicas de ensino. A seção 2 apresenta uma revisão da literatura sobre financiamentos com pagamentos vinculados à renda futura, gênero do qual os ECRs são a principal espécie. A seção 3 sumariza a metodologia empregada para gerar o painel de pessoas com nível superior e para fazer as simulaçóes de ECR, além de apresentar as estatísticas descritivas da amostra e do painel. A seção 4 discute os principais resultados. Já a seção 5 traz as conclusôes e consideraçôes finais. Adicionalmente, maior detalhamento da metodologia é apresentado nos apêndices A e B e cenários suplementares são apresentados no apêndice C.

\section{REVISÃO DE LITERATURA}

Modalidade de financiamento que, de um lado, protege o devedor contra choques futuros de renda (paga-se se e somente quando há renda para isso) e, de outro, vale-se da prerrogativa do poder público de recolher o pagamento de tributos, os financiamentos com pagamentos vinculados à renda futura têm se tornado, para muitos, modelo ideal para concessão de crédito público. Joseph Stiglitz, vencedor do Prêmio Nobel de Economia

3. Além de Austrália e Inglaterra, sistemas de ECR com maior ou menor grau de cobertura já foram introduzidos para 0 financiamento de estudantes na África do Sul, no Chile, na Coreia do Sul, nos Estados Unidos, na Etiópia, na Holanda, na Hungria, no Japão e na Nova Zelândia, havendo ainda registros de implementação de ECRs em algum momento da história em Ruanda, na Suécia, na Tailândia e na Venezuela. Sua implementação em larga escala é defendida no Chile, na Colômbia, nos Estados Unidos, na Irlanda e em alguns países asiáticos. 
em 2001, é um desses muitos. Particularmente fã dos ECRs, principal espécie de financiamento com pagamentos vinculados à renda futura, diz Stiglitz (2016, p. 129, tradução nossa): "Empréstimos com amortizaçôes condicionadas à renda (ECRs) administrados por governos representam uma importante inovaçáo social, uma melhoria em relaçáo aos mecanismos anteriores de financiamento de investimentos como a educação e agora mostram seus méritos em uma série de outras áreas."

Há uma ampla literatura sobre possibilidades de aplicação de ECRs para as mais variadas políticas públicas de financiamento. Exemplos de algumas dessas possibilidades podem ser encontrados nos diversos capítulos da coletânea de Chapman, Higgins e Stiglitz (2014). Efetivamente em aplicação, contudo, só na educação, mais especificamente para financiar escolarização não obrigatória (ensino superior e profissional).

\subsection{Os tipos de financiamento com pagamentos vinculados à renda futura}

A ideia de colocar a estrutura de coleta de tributos para arrecadar pagamentos vinculados à renda com o intuito de financiar estudos pós-secundários tem origem em Friedman (1995). Três instrumentos diferentes de financiamento com pagamentos vinculados à renda futura passaram a ser discutidos desde então, resumidos no quadro 1 .

QUADRO 1

Tipos de financiamento com pagamentos vinculados à renda futura: as principais diferenças entre ECRs, tributo do graduado e income share agreement (ISA)

\begin{tabular}{|l|l|l|}
\hline \multicolumn{1}{|c|}{ ISA } & \multicolumn{1}{|c|}{ Tributo do graduado } & \multicolumn{1}{|c|}{ ECR } \\
\hline $\begin{array}{l}\text { Modalidade de investimento (instrumento } \\
\text { financeiro de capital próprio). É o que mais se } \\
\text { aproxima da ideia original de Friedman (1995). }\end{array}$ & $\begin{array}{l}\text { Fundamentado no princípio da capacidade con- } \\
\text { tributiva: cada contribuinte deve ser tributado } \\
\text { de acordo com sua capacidade de pagamento. }\end{array}$ & $\begin{array}{l}\text { Mescla princípio da capacidade contributiva com } \\
\text { o princípio do benefício (paga-se proporcional } \\
\text { ao uso do bem ou serviço público). }\end{array}$ \\
\hline $\begin{array}{l}\text { Pessoa física ou jurídica investe na formação } \\
\text { de alguém em troca de } x \% \text { de sua renda por } n \\
\text { anos. Não há teto nem piso de pagamento. Total } \\
\text { pago é dissociado do custo dos estudos. }\end{array}$ & $\begin{array}{l}\text { A pessoa paga } x \% \text { de sua renda (por certo } \\
\text { período ou por toda a vida, com ou sem teto } \\
\text { a ser pago). Total pago é dissociado do custo } \\
\text { dos estudos. }\end{array}$ & $\begin{array}{l}\text { A pessoa paga } x \% \text { de sua renda até que sua } \\
\text { dívida seja quitada ou prescreva. Como há um } \\
\text { saldo devedor, total a ser pago é associado ao } \\
\text { custo dos estudos. }\end{array}$ \\
$\begin{array}{l}\text { Como é um investimento de risco, pode ser } \\
\text { que o investidor lucre ou tenha prejuízo. } \\
\text { Incentivo a financiar apenas estudantes de alto } \\
\text { desempenho. }\end{array}$ & $\begin{array}{l}\text { Pode gerar seleção adversa e redução da } \\
\text { demanda por ensino superior. Tende a beneficiar } \\
\text { quem faz cursos longos, caros e de baixo retor- } \\
\text { no, em detrimento de quem faz cursos curtos, } \\
\text { baratos e de alto retorno. }\end{array}$ & $\begin{array}{l}\text { Dívida remanescente pode prescrever após } n \\
\text { anos ou após aposentadoria ou morte (não } \\
\text { é condição necessária: dívida pode integrar o } \\
\text { espólio, se o ordenamento jurídico permitir). }\end{array}$ \\
\hline
\end{tabular}

Elaboração do autor. 
Os ISAs têm aflorado no Chile, na Colômbia, nos Estados Unidos e no México, segundo Bornstein (2011), sempre como instrumento financeiro destinado a catalisar investimento privado na educação pós-secundária, não como principal política pública de financiamento estudantil. ${ }^{4}$ Sendo um instrumento para atrair investimento privado, os ISAs teriam um mecanismo intrínseco de exclusão, pois investidores tenderiam a preferir estudantes mais propensos a obter altos rendimentos no futuro, propensão esta mormente associada ao capital social, econômico e cultural de suas famílias - o que dificultaria o acesso dos mais pobres a essa modalidade de financiamento de seus estudos.

Já o tributo do graduado ainda não chegou a ser implementado em lugar algum do mundo. Por não guardar relação com os custos da formação, poderia impor, para alguns, um ônus financeiro muito superior ao valor do curso. Isto poderia desencorajar parte da demanda por ensino superior como um todo ou, no mínimo, afastar muitas pessoas do ensino superior público - dado que teriam a expectativa de posterirormente serem tributados em quantia desproporcional ao valor da formação recebida. Esse risco afetaria dois tipos bem distintos de ex-alunos. Um, quem acaba obtendo um alto padrão de renda ao longo da vida, mas dissociado da educação formal que teve. O outro, egressos de cursos curtos, baratos e de alto retorno econômico, que, ante a incidência de um tributo do graduado, acabariam subsidiando indiretamente quem opta por cursos mais longos, caros e de baixo retorno. ${ }^{5}$

Quiçá por todas essas questóes, foram os ECRs que germinaram de fato. Inicialmente parecia que não prosperariam, ante o fracasso experimentado por algumas universidades americanas ao tentar, nos anos 1970, transformar em ECRs suas linhas

\footnotetext{
4. Para uma abordagem econômica aprofundada sobre ISAs, ver Palacios (2007), que os denomina de contratos de capital humano. Sob a alcunha de income share agreements (contratos de partilha de renda, em uma tradução literal) - como este tipo de investimento tem sido chamado onde já se prolifera -, ver Bair e Cooper (2019). No Brasil, ISAs não são regulamentados, embora possam ser encontradas notícias de startups e fintechs ofertando esse tipo de financiamento a partir de 2019 - ver Baraldi (2020), Startup (2020) e Le Roux (2020).

5. 0 risco relacionado ao primeiro tipo de ex-aluno poderia afetar o futuro de estudantes de diferentes backgrounds. É chamado por Barr (2001) de problema de Mick Jagger, em referência ao fato de que se tal imposto houvesse sido cobrado do vocalista da banda Rolling Stones durante toda a sua vida, seus pagamentos excederiam maciçamente os custos diretos de seus estudos não concluídos na London School of Economics and Political Science (LSE). Já Espinoza e Urzúa (2015) sugerem que o risco relacionado ao segundo tipo de ex-aluno tende a ser mais grave, pois poderia fazer com que a maior parte dos recursos arrecadados adviesse de ex-estudantes cujo background familiar remete aos estratos socioeconômicos médios e baixos, mormente o perfil de quem busca cursos curtos, baratos e de boa empregabilidade.
} 
próprias de crédito. São como política de governo que os ECRs vêm tendo sucesso, sobretudo na Austrália (desde 1989) e na Inglaterra (desde 1998), cujos sistemas hoje servem de modelo para outros países.

Há discussóes também que passam por formatos híbridos, ${ }^{6}$ que conciliam o modus operandi de um tributo com limites máximos de tempo ou de arrecadação, com o objetivo de: i) evitar que pagamentos excessivos aumentem os incentivos a comportamentos indesejáveis, como aumento das práticas de elisão fiscal, redução da oferta de trabalho ou diminuição da demanda por educaçáa (Barr et al., 2019); e ii) contornar problemas relacionados à aversão a uma dívida, que podem afastar do ensino superior alguns indivíduos simplesmente por receio de atrelar a si um saldo devedor, mesmo que com pagamentos vinculados à renda $\mathrm{e}$ em condiçôes mais vantajosas do que um contrato que possa vir a ensejar pagamentos até maiores, como em um ISA (Caetano, Palacios e Patrinos, 2019).

Há ainda a alternativa de se pensar em desenhos que congreguem ECRs e ISAs em um sistema público de financiamento estudantil. Assim defende Palacios (2019), que argumenta que ISAs oferecidos por governos não necessariamente são excludentes e podem tornar mais eficiente um sistema de financiamento com pagamentos vinculados à renda futura. Para o autor, um desenho ótimo de um programa governamental de financiamento estudantil envolveria a oferta tanto de ECRs quanto de ISAs, deixando para o estudante a decisão de qual dos dois tomar. Palacios (2019) ressalta que os ECRs podem ser entendidos como um contrato de capital humano com um limite máximo de pagamento. Tenderiam, por conseguinte, a ser escolhidos por quem antevê uma carreira promissora e bem-remunerada, enquanto os ISAs, desde que desenhados com um período de retribuição ao investidor menor do que o prazo máximo de amortização dos ECRs ofertados, tenderiam a ser o tipo de financiamento mais adequado a quem se imaginaria com rendimentos financeiros mais baixos, ao menos no horizonte de tempo em que lhe fossem cobrados os pagamentos.

Um desenho de política como o proposto por Palacios (2019) seria totalmente baseado em financiamentos com pagamentos vinculados à renda futura, mas contrasta com o que defendem Chapman (2019) e Dearden (2019a). Para estes, governos deveriam oferecer apenas ECRs propriamente ditos. Para aquele, ISAs poderiam ser ofertados pelo

6. Ver, por exemplo, o desenho de política que chegou a ser proposto durante uma campanha presidencial nos Estados Unidos e que é analisado por Chingos (2016). 
governo como alternativa aos ECRs. Onde estão em operação, os ECRs são eficazes quando são rota única de financiamento estudantil oferecido pelo Estado e valem-se do sistema de recolhimento de tributos sobre a renda para otimizar a coleta. Assim são os casos dos sistemas australiano e inglês, exemplos mais recorrentes na literatura de sistemas de ECRs de relativo sucesso. Crédito educacional com pagamento condicionado à renda não funciona táo bem em países onde esta forma de empréstimo figura apenas como um plano entre muitos disponíveis a estudantes, ainda mais se seus pagamentos nem sequer são coletados de forma automática e sobre a renda contemporânea, como nos casos dos Estados Unidos e do Chile. Teoricamente plausível, o caminho proposto por Palacios (2019) ainda não foi testado na prática, pois não há ainda exemplo concreto de uma política nacional de financiamento estudantil que seja exclusivamente baseada em pagamentos vinculados à renda futura, mas no qual coexistam ECRs e ISAs.

O ponto central de confluência das exposições de Chapman (2019), Dearden (2019a) e Palacios (2019) é que um sistema público de financiamento estudantil envolva pagamentos vinculados à renda futura cobrados pelos mesmos sistemas que recolhem tributos na fonte. Ademais, seja qual for o caminho - e isto vale também para sistemas baseados em modelos convencionais de financiamento -, se o sistema em operaçáo envolver provedores privados de ensino superior, mais necessários se tornam mecanismos de compartilhamento de riscos com as instituiçóes de ensino e/ ou mecanismos que limitem ou os preços dos cursos ou o montante de crédito a que cada estudante tem acesso, para que o financiamento público nem inflacione os custos do ensino superior nem estimule a disseminação de uma oferta de baixa qualidade.

\subsection{ECR: vantagens em relação a empréstimos convencionais, condições mínimas para sua implementação bem-sucedida e a questão dos subsídios}

Chapman e Doan (2019a) ressaltam duas vantagens-chave dos ECRs sobre financiamentos convencionais, conforme a seguir descritos.

1) Suavização do consumo e seguro contra baixa renda: como as prestaçóes limitam-se a um percentual preestabelecido da renda e normalmente há uma faixa de isenção de pagamento e regras de prescrição, os ECRs não estrangulam financeiramente seus mutuários nem pesam no orçamento em momentos de dificuldade financeira. 
2) Redução dos custos de transação e aumento de eficiência: a coleta dos pagamentos via retenção na fonte minimiza o risco de não pagamento por ato deliberado do devedor e barateia a gestão do programa.

Para que essas vantagens sejam efetivas, duas condiçōes são imprescindíveis. A primeira, que os pagamentos sejam de fato limitados a um percentual da renda do devedor, sem exigências de cobranças mínimas nem suplementares e preferencialmente garantindo-lhe algum horizonte de perdão da dívida, ainda que somente em caso de morte. ${ }^{7} \mathrm{~A}$ segunda, que a coleta dos pagamentos efetivamente utilize os mecanismos mais eficientes (e automatizados) de recolhimento de tributos.

Prestaçóes que não levam em conta a capacidade de pagamento do mutuário não devem ser parte de um ECR porque póem abaixo a sua característica de proteção contra eventuais choques momentâneos de renda e contra o risco de a renda persistir baixa ao longo de toda a vida. ECR não é o mesmo que crédito consignado; seu objetivo é minimizar riscos tanto para quem empresta quanto para quem toma emprestado. A exigência de pagamento se e somente quando a renda do mutuário ultrapassa certo patamar mínimo é característica central de um ECR e que traz consigo duas repercussóes que merecem destaque.

A primeira é o mecanismo de proteção já mencionado tanto contra situaçóes prolongadas de insuficiência econômica quanto contra dificuldades financeiras circunstanciais, que faz do ECR uma espécie de seguro, do ponto de vista do devedor. A segunda repercussão importante é que a própria característica de seguro do ECR permite que sejam cobradas taxas de juros no mínimo iguais às de títulos públicos de longo prazo emitidos pelo Tesouro Nacional - caso o crédito estudantil seja financiado por recursos públicos e operado por agentes públicos, como a Caixa Econômica Federal (Caixa) ou o Banco do Brasil (BB) - ou mesmo taxas de mercado - na hipótese de o crédito ser concedido por instituiçôes financeiras privadas e o envolvimento do poder público limitar-se à aferição da renda dos mutuários e coleta dos pagamentos vinculados à renda.

Taxas de juros em um ECR aumentam o tempo necessário para amortizar a dívida, mas não o valor das prestaçôes, sempre vinculadas à renda. Na prática, portanto, subsidiar taxas de juros em um ECR simplesmente traz perdas a quem empresta e beneficia

7. Assim é no ECR australiano. Já o ECR inglês perdoa dívidas porventura remanescentes após trinta anos do fim do período de estudos. 
quem poderia pagar a totalidade do valor presente de seu financiamento, sem que isso traga benefícios adicionais imediatos aos mais pobres. Importante notar que, para estes últimos, a característica de seguro do ECR é a proteção mais eficaz, pois lhes garante a suspensão automática dos pagamentos (sem que isso lhe confira status de inadimplente) nos momentos em que a renda permaneça abaixo do nível mínimo para a cobrança e ainda lhes subsidia ao final da vida, caso seus rendimentos ao longo dos anos tenham sido insuficientes para zerar a dívida estudantil.

Tudo isso reforça a necessidade de otimizar a coleta dos pagamentos, requisito que é também uma vantagem ímpar dos financiamentos com pagamentos vinculados à renda: a utilização da estrutura de recolhimento de tributos na fonte para automatizar ao máximo os pagamentos e vinculá-los o quanto for possível à renda contemporânea (não a rendimentos pretéritos). Isso minimiza o risco de não pagamento por ato discricionário do devedor, ao mesmo tempo em que garante que o pagamento não comprometa o bem-estar da pessoa e de sua família.

\subsection{0 fundamental envolvimento da Receita Federal na coleta de pagamentos vinculados à renda no Brasil}

A Receita Federal do Brasil (RFB) não deixa nada a dever a seus congêneres de países desenvolvidos e dispóe de avançados meios para aferição da renda e recolhimento de tributos. É essencial, portanto, seu envolvimento direto na coleta dos pagamentos de um ECR no Brasil. Isso poderia demandar alguma modificação na legislação, sem necessariamente desviar a RFB de sua missão de exercer administração tributária e aduaneira.

Três seriam os cenários possíveis para atuação da RFB em um ECR, conforme exposição de Linhares de Melo (2019).

1) Gestão tributária: o ECR seria efetivamente implementado como um imposto ou uma taxa.

2) Administração da cobrança: o ECR seria tratado como uma contribuição especial, espécie tributária da qual são subespécies, por exemplo, o salário-educação, a contribuição previdenciária, o adicional de frete para renovação da marinha mercante (AFRMM) e a contribuição patronal que mantém o Sistema S.

3) Gestão externa à RFB: o ECR não é tratado como um tributo e fica completamente à cargo de um gestor externo, o qual executa cobrança e controles, cabendo à RFB 
apenas confirmar consultas sobre os rendimentos individualizados, respeitadas as regras de sigilo fiscal.

Tanto na Austrália quanto na Inglaterra, o recolhimento dos pagamentos do ECR é tratado pela legislaçáo como análogo ao recolhimento do Imposto de Renda, para fins da atuação do Australian Taxation Office (ATO) e do HM Revenue \& Customs (HMRC), órgãos correspondentes à RFB nesses dois países. Isto não torna os ECRs desses países um tributo, embora sejam tratados como se fossem no momento do recolhimento de seus pagamentos pelo órgão de administração tributária. Em ambos os casos, há um outro órgáo público que atua como gestor do ECR, informando ao ATO (no caso da Austrália) ou ao HMRC (no caso da Inglaterra) os débitos a serem cobrados e recebendo deste os créditos correspondentes, à medida que o recolhimento dos pagamentos é feito. $\mathrm{Na}$ Austrália, cabe ao próprio Ministério da Educação a gestáo do ECR. Na Inglaterra, cabe a uma agência estatal (a Student Loans Company - SLC). Eventuais antecipaçóes voluntárias de pagamento sequer passam pelo órgão de administração tributária. Cabe ao órgão gestor do ECR viabilizar as condiçôes para que o devedor antecipe os pagamentos que desejar. É competência do Ministério da Educação (na Austrália) ou da SLC (na Inglaterra) o controle dos saldos a pagar e a atualização dos débitos pendentes que figuram nos sistemas do ATO ou do HMRC.

Os cenários colocados por Linhares de Melo (2019) levantam possibilidades de envolvimento do órgão de administração tributária em um ECR no contexto brasileiro. Tratar o ECR formalmente como um tributo facilita o envolvimento da RFB na coleta. Para fins de administração tributária, pode-se pensar no ECR como uma contribuiçấo especial cuja incidência cesse uma vez transcorrido prazo e/ou atingido o teto de contribuição preestabelecidos. Tal arranjo náo impede que seja entendido como um empréstimo pelos estudantes e suas famílias, pelas instituiçôes de ensino, pela sociedade em geral e até mesmo dentro do próprio governo (fora do âmbito da administração tributária). Basta que se adote um modelo em que o ECR seja tratado como um tributo apenas para fins de administração tributária.

A princípio, portanto, o segundo cenário colocado por Linhares de Melo (2019), em que a RFB atua na administraçáo da cobrança (como faz no recolhimento de contribuiçóes especiais), parece ser o mais adequado. Esse caminho permitiria desenhar um ECR propriamente dito, que deixa evidente os preços relativos dos cursos, bem como a dívida de cada pessoa e quanto efetivamente conseguiu pagar ao longo da vida. Permite 
também que se viabilize algum subsídio cruzado, com os egressos mais ricos arcando com parte dos custos do não pagamento dos egressos mais pobres. ${ }^{8}$ Ademais, como esse formato pressupóe um órgão gestor da política (a quem caberia, no mínimo, fornecer à RFB os débitos e dela receber os créditos), poder-se-ia estruturar um modelo mais próximo do que propóe Palacios (2019), em que coexistam ECRs e ISAs oferecidos pelo Estado, e ainda atribuir a esse órgão gestor um caráter de agência reguladora. Um formato assim daria consistência a um sistema público de financiamentos vinculados à renda futura, congregando programas governamentais de financiamento estudantil e um mercado de ECRs e ISAs, no qual poderiam operar instituiçôes financeiras públicas e privadas sob a regulação e fiscalização de uma agência estatal - enquanto a participação da RFB se limitaria à administração da cobrança, papel que respeita o escopo de sua missão legal (exercer administração tributária e aduaneira). Este caminho seria mais transparente do que simplesmente incidir um tributo do graduado - além dos eventuais desdobramentos tributários que uma solução baseada em um imposto ou taxa decerto ensejaria e que precisariam ser bem estudados.

Vale destacar que o terceiro cenário posto por Linhares de Melo (2019) - que ele chama de gestão externa à RFB - tende a ser o de mais rápida operacionalização, pois bastaria previsão em lei ordinária para que: i) o contrato de financiamento estudantil tenha cláusula em que o estudante abre seu sigilo fiscal para que futuramente seja feito o recolhimento de pagamentos vinculados à sua renda; ii) o(s) agente(s) operador(es) do ECR tenha(m) competência para exigir recolhimento na fonte dos pagamentos vinculados à renda de ex-estudantes que tenham débitos estudantis; e iii) a RFB transmita ao(s) agente(s) operador(es) do ECR as informações fiscais necessárias à confirmação de que o recolhimento feito na fonte foi feito corretamente. Este cenário, contudo, impóe um custo de transação desnecessário em um ECR. Se uma das grandes vantagens dos modelos baseados em pagamentos vinculados à renda é justamente se valer da eficiência dos mecanismos de coleta de tributos para otimizar os pagamentos do financiamento educacional, não faz sentido reduzir a RFB a um papel meramente consultivo. Não é recomendável, pois, que o órgão gestor do ECR acumule ao mesmo tempo a atribuição legal de recolher os pagamentos vinculados à renda.

8. Embora, como ressaltado no quadro 1, esse subsídio cruzado tenderia a beneficiar egressos de cursos longos, caros e de baixo retorno, em detrimentos de egressos de cursos curtos, baratos e de alto retorno. Seriam os egressos de maior renda os que continuariam a pagar mais, mas há aí uma questão intertemporal no debate sobre justiça social do tributo do graduado que não é trivial, caso os cursos mais curtos, baratos e de retorno relativamente elevado tendam a concentrar estudantes oriundos de famílias de baixa renda, como argumentam Espinoza e Urzúa (2015). 
Outra questão de relevo é a definição das fontes de renda sobre as quais incidisse a alíquota desse tributo ou a taxa de reembolso desse ECR. Ideal que incidisse sobre todas as fontes de renda pessoal (salários, pró-labore, rendimentos de aplicaçóes financeiras, lucros, dividendos, heranças), a fim de maximizar pagamentos, particularmente entre os não assalariados. É necessário estudar detalhadamente essa questão para otimizar a cobrança, mas tenderiam a ser mais políticas do que técnicas as dificuldades para vincular pagamentos dessa natureza a fontes outras além do salário. ${ }^{9}$ Trata-se de uma discussão pertinente também aos ISAs. Por terem um caráter de investimento e, por conseguinte, poderem mais facilmente envolver entes privados tanto do lado de quem financia os estudos quanto do lado de quem tem seus estudos financiados, os ISAs têm peculiaridades que decerto demandariam discussôes jurídicas mais específicas quanto ao papel do Estado no recolhimento dos pagamentos vinculados à renda, discussóes essas que escapam ao escopo deste trabalho.

De todo modo, já há metodologias disponíveis para simular a expectativa de arrecadação de pagamentos vinculados à renda, com base no perfil socioeconômico atual ou recente de egressos do ensino superior. Este trabalho se vale de uma dessas metodologias para simular a expectativa de recuperação de crédito em face a variados desenhos de ECR. É um exercício que simula o quanto brasileiras e brasileiros com curso superior completo conseguiriam pagar de volta se a RFB lhes recolhesse pagamentos de um ECR para retribuir o Estado pelo investimento feito em sua formação superior - como se todas as pessoas da amostra, independentemente do tipo de instituição onde se formaram, tivessem tido seus estudos superiores integralmente financiados por recursos públicos. A seção 3 discute que dados são necessários para essa finalidade, descreve os que foram usados neste trabalho e resume o método de simulação utilizado. O exercício de simulação descrito a seguir permite vislumbrar os potenciais impactos fiscais e distributivos de diferentes desenhos de ECR para o Brasil.

9. Como destacam Fernandes, Campolina e Silveira (2018), o fenômeno conhecido no Brasil como pejotização mecanismos variados que permitem a muitos indivíduos atuarem no mercado de trabalho como firmas individuais - afeta a equidade e a receita do sistema de tributação da renda pessoal. Vincular os pagamentos de um ECR a toda e qualquer fonte de renda pessoal torna-se, assim, imprescindível para otimizar o recolhimento dos pagamentos. Enquanto houver incentivo no Brasil para profissionais autônomos com bom padrão de renda atuarem no mercado de trabalho como se fossem firmas individuais para pagarem menos Imposto de Renda, seria o caso de discutir, inclusive, a incidência de pagamentos de um ECR sobre a receita de firmas individuais. 


\section{DADOS E MÉTODO}

As simulaçóes deste trabalho seguem metodologia descrita por completo em Dearden (2019b), replicada com dados brasileiros em Nascimento (2018) e em Dearden e Nascimento (2019). Esta seção discute os dados utilizados neste trabalho e resume o método Dearden, com algum detalhamento a mais disponível nos apêndices A e B.

\subsection{Porque são necessárias informações individualizadas para avaliar o desempenho de programas de financiamento estudantil}

O método Dearden exige dados longitudinais (em painel) ao nível do indivíduo, e não apenas informaçóes agregadas. Entender como variam ao longo do tempo certas condiçôes e características individuais é imprescindível para vários campos de pesquisa aplicada, seguramente também para avaliações ex ante e ex post de políticas públicas. Nascimento (2016) destaca, a partir de um exemplo construído por Dynarski (2015), a necessidade de informaçóes individualizadas (microdados) para apurar melhor problemas relacionados a financiamento estudantil e quais seriam as medidas mais eficazes para contorná-los, sendo válido replicar aqui o trecho em questáo.

Considere-se a hipótese de um programa tradicional de financiamento estudantil (sem ECR) em que pequenos empréstimos apresentem taxas superiores de inadimplência em relação às registradas para grandes empréstimos. Uma situação assim seria consistente com dois cenários alternativos, cada um dos quais acarretando implicaçôes bem diferentes de política.

Em um desses cenários, os inadimplentes apresentam baixo rendimento justamente durante a parte de sua vida produtiva em que vencem as parcelas dos seus financiamentos estudantis. Neste caso, a migração do programa para um ECR, ao reduzir os pagamentos durante períodos de baixa renda, representaria uma segurança financeira para os beneficiários. Ao mesmo tempo, se o padrão de renda dessas pessoas se elevar ao longo da vida, o governo poderá recuperar maiores proporçóes dos recursos emprestados.

\section{$(\ldots)$}

O outro cenário possível seria o de que o padrão de renda dessas pessoas ao longo da vida se mantenha em patamar baixo, de forma que boa parte delas não demonstre capacidade de suportar sequer pequenos pagamentos. Neste caso, um ECR continuaria a ser mais vantajoso para essas pessoas do que o financiamento tradicional, mas os custos para o governo seriam bem mais elevados, tendo em vista que parcela significativa de muitos dos empréstimos acabaria sendo perdoada. 
A não ser que tenha sido implantado com o objetivo específico de viabilizar o pagamento de ao menos parte de débitos estudantis pré-existentes, o custo de conceder, administrar e perdoar esses empréstimos tornaria programas de bolsas e/ou a manutenção/expansão de sistemas públicos totalmente gratuitos alternativas mais custo-efetivas para o contribuinte.

Distinguir esses dois cenários requer dados longitudinais ao nível do indivíduo, que forneçam informações tocantes à evolução da renda e ao acesso a condiçôes de crédito, pois a maneira mais confiável de capturar choques de renda contra os quais programas de ECR oferecem proteção é acompanhando os mesmos grupos de indivíduos ao longo do tempo. Análises a partir apenas de médias suavizariam choques que acometem grupos com características específicas, enviesando as estimativas dos benefícios e dos custos da introdução do ECR. (Nascimento, 2016, p. 54-55).

O mínimo necessário para se simular impactos fiscais e distributivos de um ECR é dispor de informaçôes coletadas em diferentes anos sobre renda e idade de cada indivíduo de pelo menos uma coorte inteira de egressos do ensino superior. Impactos fiscais e distributivos podem ainda ser simulados separadamente por sexo e, a depender do tamanho da amostra e da disponibilidade de dados, também por etnia, região, área de formação, entre outros recortes. Simulações mais avançadas demandariam informaçóes sobre renda, idade e algumas características pessoais também dos membros do domicílio dos indivíduos com nível superior que compóem a amostra de "devedores" do ECR a ser simulado e, se possível, até dados sobre outros financiamentos contratados e débitos vencidos e porventura não pagos pelos próprios egressos e por outros membros de seu domicílio. Isto permitiria calibrar melhor os percentuais a serem vinculados à renda para pagamento do ECR, de forma a não só maximizar a taxa de recuperação do crédito concedido como também manter os pagamentos dentro de um patamar que não comprometa o bem-estar do egresso ou daqueles que dele dependam financeiramente.

O método Dearden permite incorporar todos esses recortes, desde que haja dados disponíveis. Sua grande vantagem, no entanto, é gerar perfis dinâmicos de idade-renda a partir de observaçóes sobre rendimentos, escolarização e idade coletadas dos mesmos indivíduos em apenas dois anos consecutivos. Painéis longos, em que indivíduos são acompanhados ao longo de vários anos, fornecem aproximaçóes muito melhores de padrôes de mobilidade de renda, ${ }^{10}$ porém frequentemente não estão disponíveis. $\mathrm{O}$ método

10. Painéis de longa duração são rotineiramente utilizados na Austrália e na Inglaterra para avaliar o desempenho dos seus sistemas de ECR. Ver, por exemplo, os trabalhos de Higgins e Sinning (2013) e de Britton, Shephard e Van der Erve (2019), respectivamente, sobre o ECR da Austrália e sobre o ECR da Inglaterra. 
Dearden também pode ser aplicado a painéis de longa duração, mas é uma contribuição metodológica particularmente valiosa para contextos que carecem de dados em painel com tamanhos de amostra razoavelmente grandes $(N)$ e cobertura de curto a médio prazo $(T)$. Projeta-se para o futuro o padrão de mobilidade de renda observado para dois ou mais anos consecutivos, para daí gerar os perfis dinâmicos de idade-renda sobre os quais são simulados os pagamentos do ECR.

\subsection{Dados do Brasil que poderiam ser aplicados neste trabalho}

No contexto do Brasil, registros fiscais individuais seriam a fonte ideal de informações para avaliação ex ante de um ECR. Os rendimentos de pessoas formadas em anos recentes seriam usados para simular seus padrôes de mobilidade ao longo do tempo, para daí serem simulados os pagamentos vinculados à renda a serem recolhidos na fonte pela RFB. O governo federal é, portanto, capaz de acessar dados de qualidade para proceder a avaliaçôes ex ante de possíveis desenhos de programas governamentais de crédito educacional. No entanto, para pesquisadores, o acesso a registros e débitos tributários individuais é muito restrito, o que exige recorrer a outras bases de dados para simular essas políticas.

Para além de questôes de sigilo fiscal, interpretaçôes acerca do grau de confidencialidade envolvendo microdados identificados costumam impor barreiras também ao acesso de pesquisadores a registros administrativos dos mais diversos tipos quando é necessário também dispor do registro no Cadastro de Pessoas Físicas (CPF) e dos nomes dos indivíduos. Embora sejam justamente essas as variáveis-chave para combinar entre si diferentes bases de dados, há uma frequente dificuldade de entendimento entre operadores do direito sobre o porquê de ser táo necessário o acesso de pesquisadores a essas informaçôes e sobre qual o uso que delas é efetivamente feito para fins de pesquisa aplicada. Enquanto não houver uma política nacional de tratamento e uso de informaçóes sigilosas para fins de pesquisa aplicada e de avaliação e acompanhamento de políticas públicas, perde-se o vasto potencial que têm os variados registros administrativos e estatísticos brasileiros para contribuir para a melhoria e maior transparência da ação do Estado.

Dito isso, uma alternativa a dados fiscais seria combinar registros administrativos das próprias instituiçôes de ensino ou de bases mantidas pelo governo federal, como os microdados dos Censos da Educação Superior ou do Exame Nacional de Desempenho de Estudantes (Enade), com os registros administrativos do Relatório Anual de Informaçôes Sociais (Rais), espécie de censo anual do mercado formal de trabalho que 
o governo federal anualmente exige dos empregadores brasileiros. A base de dados formada a partir da junção desses registros administrativos forneceria dados em painel com $N$ (amostras) e $T$ (coberturas no tempo) razoavelmente extensas. Assim seria possível simular a dinâmica dos rendimentos pessoais.

Embora possam ser parcialmente disponibilizados a pesquisadores, mediante solicitação formal aos órgãos federais que os tutelam, há uma limitação relevante afeita à utilizaçáo desses conjuntos de registros administrativos para simular um ECR: vincular-se-ia os hipotéticos pagamentos da simulação apenas a percentuais de salários e vencimentos de empregos formais, limitando seu alcance a descontos em folha. Como já discutido antes, o bom funcionamento de um ECR no Brasil exigiria idealmente desconto automático dos pagamentos também em outras fontes de renda, de forma a agilizar e maximizar os pagamentos por parte de pessoas de nível superior cujas principais fontes de renda não advêm de remuneração em empregos formais.

Se a opção de política for restringir a coleta de pagamentos de um ECR à remuneração em postos formais de trabalho, os microdados da Rais isoladamente (sem precisar, portanto, do $\mathrm{CPF}$ e do nome das pessoas) são suficientes para fornecer um painel de indivíduos para as simulaçôes. Não obstante, além da limitaçáo de deixar de fora outras fontes de renda, ao recorrer somente aos microdados da Rais deixar-se-ia de estimar os montantes que nunca seriam pagos, pois não se saberia o quão representativo da coorte de egressos do ensino superior seria o painel de pessoal ocupado com diploma de nível superior.

Alternativas incluiriam ainda usar dados de Censos Demográficos ou das pesquisas domiciliares realizadas pelo Instituto Brasileiro de Geografia e Estatística (IBGE). Os Censos Demográficos ocorrem no Brasil a cada dez anos. Informaçóes detalhadas coletadas por um questionário amostral fornecem os dados necessários para os fins ora discutidos, mas apenas para simulaçóes estáticas da renda vitalícia dos graduados, pois os respondentes de tal questionário em uma edição do censo não são os mesmos respondentes de outras ediçóes.

Dados semelhantes estão disponíveis nas edições anuais da Pesquisa Nacional por Amostra de Domicílio (PNAD), coletadas transversalmente todos os anos de 1976 a 2015 (exceto em anos de Censos Demográficos). Em 2012, um novo desenho com 
painéis rotativos passou a coexistir com a PNAD até então padrão. O novo desenho é chamado de PNAD Contínua. Desde 2016, A PNAD Contínua passou a ser a única pesquisa domiciliar nacional aplicada no Brasil pelo IBGE. A pesquisa coleta dados trimestrais sobre indicadores de força de trabalho, com domicílios que permanecem na amostra por até cinco trimestres. Possibilita, portanto, a construção de um painel de indivíduos, com dois anos consecutivos de observaçóes sobre renda, idade e escolaridade. Essa é a condição necessária e suficiente para simular os padróes de amortização de um hipotético desenho de ECR pelo método aplicado neste trabalho. Embora o ideal seja realizar tais simulaçóes usando dados longitudinais mais longos, as simulaçôes feitas com um painel de curta duração já representam uma grande melhoria na qualidade das avaliações ex ante de programas de financiamento desse tipo, em relação a avaliações baseadas em simulações feitas com informações sobre renda e idade coletadas em um único momento do tempo. ${ }^{11}$

\subsection{Os dados utilizados neste trabalho}

As ediçóes de 2014 e de 2015 da PNAD Contínua são usadas neste trabalho tanto para simular perfis estáticos de idade-renda (que desconsideram a mobilidade de renda) quanto para construir um painel curto para as simulaçóes dinâmicas (que levam em conta a mobilidade dos indivíduos entre os percentis da distribuição de renda ao longo dos anos). A análise envolve homens e mulheres de nível superior com idades entre 24 e 64 anos. Esta faixa etária foi escolhida porque, por simplicidade, supóe-se nas simulaçóes que todas as pessoas concluem aos 23 anos um curso de graduação de quatro anos de duração. ${ }^{12}$ Esta era a idade modal para concluintes, segundo os dados reportados nos últimos anos pelos Censos da Educação Superior. Supõe-se, ademais, que todas adentram o mercado de trabalho aos 24 anos com seus diplomas de graduação, permanecendo ativas até completarem 65 anos, que era a idade mínima inicialmente proposta para a aposentadoria em uma reforma do sistema previdenciário em análise no Congresso

11. Quando apenas dados transversais são disponíveis, simular as amortizações de um programa de financiamento impõe desconsiderar mobilidade de renda, como se durante a vida inteira todo e qualquer indivíduo da amostra permanecesse estanque na mesma parte da distribuição de renda. Para um exemplo de simulação assim, ver as estimativas que Chapman e Lounkaew (2015) fazem do nível de comprometimento da renda nos diferentes decis da distribuição de rendimentos de pessoas com nível superior nos Estados Unidos, quando Ihes são atribuídas dívidas estudantis compatíveis com o principal programa federal de crédito educacional existente à época naquele país.

12. O sistema de ensino superior brasileiro inclui cursos de graduação com diferentes durações, mas não é possível saber que cursos fizeram os indivíduos pesquisados pelas PNADs Contínuas. As simulações assumem que um curso de graduação típico dura quatro anos, porque a maioria dos alunos está matriculada em cursos de quatro anos. 
Nacional brasileiro quando este trabalho estava em elaboração. Nas simulações, quem chega aos 65 anos sem ter pagado tudo tem sua dívida remanescente perdoada.

As amostras para os anos de 2014 e 2015 totalizaram 147.319 observaçóes, 39,2\% das quais se referem a homens e $60,8 \%$ a mulheres. O painel com pessoas com nível superior que aparecem em ambos os anos consecutivos é composto de 25.240 indivíduos, $38,4 \%$ dos quais são homens e $61,6 \%$ são mulheres. Há proporção significativamente maior de mulheres na amostra porque, como mostram Beltrão e Alves (2009), a reversão do hiato de gênero na conclusão do ensino superior aconteceu no Brasil nos anos 1970, crescendo nas décadas seguintes a proporção de mulheres entre pessoas com nível superior. Todos os graduados são incluídos na análise, mesmo quem reporta rendimento zero. Como Higgins e Sinning (2013) destacam, deve-se incluir neste tipo de análise quem não dispunha de renda no período, porque é necessário conhecer a proporção de graduados que não seriam capazes de pagar suas dívidas se tivessem contraído financiamentos estudantis.

A tabela 1 apresenta as estatísticas descritivas dos rendimentos, da idade e do número de graduados por sexo na amostra completa de pessoas com nível superior extraídas das ediçóes de 2014 e de 2015 da PNAD Contínua. 
TABELA 1

Estatísticas descritivas para a amostra completa de pessoas com nível superior nas edições de 2014 e de 2015 da PNAD Contínua

\begin{tabular}{|c|c|c|c|c|}
\hline \multicolumn{5}{|c|}{ Amostra completa } \\
\hline & & $\begin{array}{r}\text { Todas as pessoas com } \\
\text { nível superior }\end{array}$ & Homens com nível superior & Mulheres com nível superior \\
\hline \multirow{2}{*}{$\begin{array}{l}\text { Renda bruta } \\
\text { total em } \\
2014 \text { (R\$) }\end{array}$} & Média & $53.779,94$ & $75.183,00$ & $39.393,04$ \\
\hline & (DP) & $(77.972,38)$ & $(100.458,80)$ & $(53.553,17)$ \\
\hline \multirow{2}{*}{$\begin{array}{l}\text { Renda bruta } \\
\text { total em } \\
2015 \text { (R\$) }\end{array}$} & Média & $51.679,72$ & $71.580,89$ & $38.147,39$ \\
\hline & (DP) & $(71.355,40)$ & $(87.547,27)$ & $(53.756,42)$ \\
\hline \multirow{2}{*}{$\begin{array}{l}\text { Idade em } 2014 \\
\text { (em anos) }\end{array}$} & Média & 39,9 & 40,2 & 39,7 \\
\hline & (DP) & $(11,1)$ & $(11,3)$ & $(11,0)$ \\
\hline \multicolumn{2}{|c|}{ Proporção com renda zero em 2014 (\%) } & 16,9 & 10,4 & 21,1 \\
\hline \multicolumn{2}{|c|}{ Proporção com renda zero em 2015 (\%) } & 18,3 & 11,4 & 22,7 \\
\hline \multicolumn{2}{|c|}{$\begin{array}{l}\text { Proporção com renda zero em ambos } \\
\text { os anos (\%) }\end{array}$} & Não se aplica & Não se aplica & Não se aplica \\
\hline \multicolumn{2}{|c|}{$\begin{array}{l}N \text { (pessoas com nível superior com idade } \\
\text { entre } 24 \text { e } 64 \text { anos) }\end{array}$} & $\begin{array}{l}\text { 2014: } 72.405 \\
\text { 2015: } 74.914\end{array}$ & $\begin{array}{l}\text { 2014: } 28.453 \\
\text { 2015: } 29.346\end{array}$ & $\begin{array}{l}\text { 2014: } 43.952 \\
\text { 2015: } 45.568\end{array}$ \\
\hline
\end{tabular}

Fontes: PNADs Contínuas 2014 e 2015.

Obs.: 1. DP = desvio-padrão.

2. Os pesos amostrais foram aplicados.

3. Os rendimentos foram deflacionados para os preços médios de 2017, utilizando o Índice de Preço ao Consumidor Amplo (IPCA).

4. Por pessoas com nível superior entenda-se todos os indivíduos que reportaram superior completo como nível de instrução mais elevado alcançado.

A partir dos dados da amostra descrita na tabela 1 montou-se um painel com todas as pessoas com nível superior que responderam aos questionários de 2014 e de 2015 da PNAD Contínua. Para isso foi necessário gerar um identificador que fosse único para cada indivíduo presente na amostra completa. O IBGE especifica um identificador para aninhar os indivíduos em seus respectivos domicílios, mas um identificador único para cada pessoa e apropriado a ser usado para painéis no nível do indivíduo ainda estava por ser incorporado às ediçôes da PNAD Contínua lançadas até o momento do fechamento deste trabalho. Por isso que, além das variáveis necessárias para formar o identificador sugerido pelo IBGE para aninhar os indivíduos a seus domicílios, foram também concatenadas as variáveis referentes a dia, mês e ano de nascimento, mais uma variável dummy para sexo. Foram, portanto, excluídas todas as observaçóes que não informam adequadamente data de nascimento e sexo. Esse foi o procedimento adotado para gerar um identificador único para cada pessoa e daí formar o painel de indivíduos pesquisados nesses dois anos consecutivos de PNAD Contínua. 
As estatísticas descritivas do painel estão reportadas na tabela 2. Como se vê, a composição do painel final usado para simular as amortizaçôes dos ECRs hipotéticos assemelha-se bastante ao da amostra completa, em termos de proporção de homens e de mulheres e de média e desvio-padrão das variáveis de interesse.

TABELA 2

Estatísticas descritivas para o painel final usado para as simulações

\begin{tabular}{|c|c|c|c|c|}
\hline \multicolumn{5}{|c|}{ Painel final usado para as simulações } \\
\hline & & Todas pessoas com nível superior & Homens com nível superior & $\begin{array}{l}\text { Mulheres com nível } \\
\text { superior }\end{array}$ \\
\hline \multirow{2}{*}{$\begin{array}{l}\text { Renda bruta total } \\
\text { em } 2014 \text { (R\$) }\end{array}$} & Média & $56,454.53$ & $79.896,78$ & $41.217,58$ \\
\hline & (DP) & $(73,821.12)$ & $(93.605,60)$ & $(52.034,51)$ \\
\hline \multirow{2}{*}{$\begin{array}{l}\text { Renda bruta total } \\
\text { em } 2015 \text { (R\$) }\end{array}$} & Média & $55,007.19$ & $76.977,47$ & $40.724,45$ \\
\hline & (DP) & $(73,566.29)$ & $(87.478,38)$ & $(58.635,09)$ \\
\hline \multirow{2}{*}{$\begin{array}{l}\text { Idade em } 2014 \\
\text { (em anos) }\end{array}$} & Média & 40.7 & 41,1 & 40,4 \\
\hline & (DP) & $(11.1)$ & $(11,2)$ & $(11,0)$ \\
\hline \multicolumn{2}{|c|}{ Proporção com renda zero em 2014 (\%) } & 16.0 & 9,7 & 20,1 \\
\hline \multicolumn{2}{|c|}{ Proporção com renda zero em 2015 (\%) } & 17.2 & 10,2 & 21,7 \\
\hline \multicolumn{2}{|c|}{$\begin{array}{l}\text { Proporção com renda zero em ambos } \\
\text { os anos (\%) }\end{array}$} & 12,7 & 6,9 & 16,3 \\
\hline \multicolumn{2}{|c|}{$\begin{array}{l}N \text { (pessoas com nível superior com idade } \\
\text { entre } 24 \text { e } 64 \text { anos) }\end{array}$} & 25.240 & 9.697 & 15.473 \\
\hline
\end{tabular}

Fontes: PNADs Contínuas 2014 e 2015.

Elaboração do autor.

\subsection{0 método Dearden}

Seguindo Dearden (2019b), as simulações aplicam funções de cópula para captar padrões de mobilidade na distribuição de rendimentos das pessoas com nível superior de nossa amostra. ${ }^{13}$ Os rendimentos individuais em cada ano são transformados nas suas funçôes de distribuição acumuladas (FDA) para cada idade $t\left(u_{i t}\right.$ e $\left.u_{i t+1}\right)$, de tal maneira que haverá uma única função de cópula bivariada $C_{t}$ tal que:

13. Ver também Bonhomme e Robin (2009). 


$$
C_{t}\left(F\left(u_{t}\right), F\left(u_{t+1}\right)\right)=C_{t}\left(u_{t}, u_{t+1}\right), t=24,25, \ldots 64
$$

As distribuições marginais $F\left(u_{t}\right)$ e $F\left(u_{t+1}\right)$ são modeladas usando 100 percentis. Daí então a cópula bivariada que melhor capta a distribuição conjunta das marginais adjacentes (essencialmente a matriz de transição contínua) para cada transição de idade dos 24 até os 64 anos é usada nas simulaçóes. A cópula bivariada que melhor captou a distribuição conjunta do painel com dados das PNADs Contínuas 2014 e 2015 foi a student's t copula ( $t$-cópula).

O passo seguinte foi estimar os parâmetros relevantes para a $t$-cópula: a correlação rho $(\rho)$ e os graus de liberdade $(v)$, cujos resultados estão reportados no apêndice A. Quanto maior o parâmetro $\rho$, menor a mobilidade na distribuição de rendimentos dos graduados; quanto menor o parâmetro $v$, menor a mobilidade nas caudas da distribuição renda. Como esperado, os resultados obtidos para os dois parâmetros neste trabalho descrevem um padrão de mobilidade de renda muito menor no Brasil do que o padrão de mobilidade de renda encontrado por Dearden (2019b) para os Estados Unidos - a comparação é possível por ser aplicada neste trabalho a mesma metodologia que o artigo de Dearden aplicou para dados amostrais dos Estados Unidos.

O que interessa para fins da presente análise, contudo, é que os parâmetros $\rho$ e $v$ são usados para projetar os padróes de mobilidade de renda das pessoas com nível superior, permitindo simular a amortização do financiamento sobre perfis dinâmicos de idade-renda do pessoal com nível superior. Os padrôes de amortização são então simulados para hipotéticos desenhos de ECR, considerando uma pseudoamostra de 10 mil homens e 10 mil mulheres. Nas simulações dinâmicas, são replicados nessa pseudoamostra o perfil de idade-renda e de mobilidade obtidos no painel. Já as simulaçôes estáticas não usam os parâmetros $\rho$ e $v$ - ao invés disso, replicam para todos os anos da simulação o perfil de idade-renda obtido com dados do ano de $2014 .{ }^{14} \mathrm{Com}$ ou sem mobilidade, os rendimentos de cada indivíduo da pseudoamostra mudam ano a ano conforme a taxa de crescimento real estabelecida para a simulação.

14. Ver mais sobre as simulações estáticas no apêndice B. 
Em suma, os indivíduos transitam por diferentes decis de renda nas simulaçóes dinâmicas, mas nas simulações estáticas permanecem no mesmo decil durante toda a vida. Assim, nas simulaçóes dinâmicas uma mesma pessoa pode estar na cauda inferior da distribuição de renda em determinado período e vir a estar na mediana ou na cauda superior em outro período, sendo que a mobilidade observada na simulação respeita os padróes de mobilidade observados nos dois anos da análise e captado pelos parâmetros $\rho$ e $v$. Já nas simulaçôes estáticas, quem não tinha renda no ano inicial segue assim durante todos os anos da simulação, como também quem estava no meio da distribuição de renda ou quem estava no topo.

Seja nas simulaçóes estáticas seja nas simulaçóes dinâmicas, os padrões de rendimento encontrados para a pseudoamostra de 10 mil homens e 10 mil mulheres são ajustados de acordo com os pesos amostrais calculados com base na proporção de homens e de mulheres entre os concluintes de cursos presenciais de graduação reportados no Censo da Educação Superior de 2019. Em todas as simulaçôes, os empréstimos variam de R \$ 5 mil a $\mathrm{R} \$ 300$ mil, com o valor médio sendo de $\mathrm{R} \$ 50$ mil e desvio-padrão de $\mathrm{R} \$$ 25 mil. O que muda em cada cenário são os parâmetros da política (taxa real de juros, alíquotas de cobrança, se há ou não faixa de isenção e faixas diferentes de cobrança). Todos os cenários apresentados na seçấo 4 supóem um crescimento real médio de 1\% ao ano (a.a.) na renda das pessoas de nível superior, inflação em 3,75\% a.a. e o custo de financiamento do governo (já descontada a inflação) em $2,8 \%$ a.a. ${ }^{15}$ Os resultados permitem avaliar as implicaçôes fiscais e distributivas de cada desenho simulado.

\section{RESULTADOS E DISCUSSÃO}

Ao todo, dezenas de desenhos alternativos de ECR foram simulados na preparação deste trabalho. Alguns são apresentados nesta seção e outros, no apêndice C.

15. 0 custo de financiamento do governo pode ser entendido como o seu custo de oportunidade. Variadas podem ser as taxas tomadas para este fim. Recorreu-se, neste trabalho, à mediana dos valores da Taxa de Longo Prazo (TLP), divulgados pelo Banco Nacional de Desenvolvimento Econômico e Social (BNDES) em: <https://bit.ly/2XHQHXH>, acesso em 15 maio 2019, para o período de janeiro de 2018 a maio de 2019. Foram simulados outros cenários mudando os pressupostos adotados para a evolução da renda real ao longo dos anos e para o custo de financiamento do governo. Alguns desses outros cenários estão disponíveis no apêndice $C$. 


\subsection{0 cenário preferencial}

Os melhores desenhos, em termos de acessibilidade para graduados e tamanho dos subsídios do contribuinte, envolvem ECRs com sobretaxas de 25\% adicionadas aos montantes iniciais dos empréstimos, taxas de juros no nível do custo de financiamento do governo cobradas depois de finalizado o curso, juro real zero durante a fase de estudos e para egressos com renda dentro da faixa de isenção do Imposto de Renda Pessoa Física (IRPF) e taxas progressivas de pagamento alinhadas com as faixas de tributação da renda pessoal e equivalentes à metade das respectivas alíquotas para fins de IRPF. A tabela 3 permite visualizar mais facilmente esses parâmetros.

TABELA 3

Parâmetros do cenário preferencial de ECR

\begin{tabular}{|c|c|c|c|}
\hline & Faixas de renda do IRPF 2017 (R\$) & $\begin{array}{c}\text { Vinculação da renda para } \\
\text { pagar o ECR } \\
(\%)\end{array}$ & $\begin{array}{c}\text { Alíquota do IRPF } \\
(\%)\end{array}$ \\
\hline 1 & Até 22.847,76 (faixa de isenção) & 0 & 0 \\
\hline 2 & Entre $22.847,77$ e $33.919,80$ & 3,75 & 7,5 \\
\hline 3 & Entre $33.919,81$ e $45.012,60$ & 7,5 & 15,0 \\
\hline 4 & Entre $45.012,61$ e $55.976,16$ & 11,25 & 22,5 \\
\hline 5 & Acima de $55.976,16$ & 13,75 & 27,5 \\
\hline \multicolumn{4}{|c|}{ Índice de correção do saldo devedor } \\
\hline \multicolumn{2}{|c|}{ Durante o curso } & Inflação & \\
\hline \multirow{2}{*}{$\begin{array}{l}\text { Após o } \\
\text { curso }\end{array}$} & Nos anos em que rendimentos não ultrapassam faixa de isenção & Inflação & \\
\hline & Nos anos em que rendimentos são superiores à faixa de isenção & TLP & \\
\hline
\end{tabular}

É adicionada uma sobretaxa de $25 \%$ ao montante inicial do empréstimo. Isso ajuda a reduzir o custo fiscal do juro real zero durante o curso e para egressos com renda abaixo do limite de isenção. Trata-se, na prática, de um mecanismo de subsídio cruzado, pois só paga efetivamente essa sobretaxa quem consegue pagar de volta $100 \%$ do financiamento.

Elaboração do autor.

Obs.: 1. Informações concernentes à tabela progressiva do IRPF 2017 obtidas em: <https://bit.ly/2JwuV6a>. Acesso em: 30 jun. 2018.

2. Inflação em 3,75\% a.a., equivalente ao centro da meta para o ano de 2021, a mais recente estipulada pelo Banco Central do Brasil (BCB) até o momento de finalização deste trabalho - Resolução no $4.671 / 2018$ do BCB.

3. Taxa real de juros igual à taxa real de desconto, que, por sua vez, é igual ao custo de financiamento do governo, aqui tomado como a mediana da TLP observada entre janeiro de 2018 e maio de 2019 (2,8\% a.a., já deduzida a inflação).

4. Supõe-se rendimentos brutos crescendo a uma taxa real média de $1 \%$ a.a.

Dois desenhos são possíveis com os parâmetros reportados na tabela 3: um com alíquotas progressivas incidindo sobre toda a renda bruta aferível e outro em que, tal qual no IRPF, cada alíquota incide apenas sobre a faixa de renda a que estão associadas. A opção por alíquotas marginais suaviza mudanças no patamar de cobrança em torno dos pontos de corte, mas também implica uma taxa de recuperação de crédito bem menor do que quando as mesmas alíquotas são aplicadas sobre toda a renda bruta aferida. 
Barr et al. (2019) recomendam a aplicação de alíquotas marginais para evitar descontinuidades acentuadas nos rendimentos dos graduados, distorção que pode estimular, por exemplo, reduçóes na oferta de força de trabalho e/ou práticas de elisão e de evasão fiscal em torno dos pontos de corte. O ECR inglês faz uso de alíquotas marginais, ao passo que o ECR australiano aplica suas alíquotas sobre a renda total, isto é, ao mudar de faixa de renda a pessoa paga a nova alíquota sobre todo o seu rendimento, náo apenas sobre a parcela que superou a faixa anterior.

Dois estudos minimizam as potenciais distorções lembradas por Barr et al. (2019). Chapman e Leigh (2009) mostram evidência de concentração de contribuintes australianos com rendimentos próximos ao limite superior da faixa de isenção de pagamentos do ECR (indício de elisão ou até mesmo de evasão fiscal), mas ressaltam que os resultados encontrados, embora estatisticamente significativos, não se mostram grandes o suficiente para serem economicamente relevantes. Trinta anos após a implementação original, o ECR australiano tem dez diferentes alíquotas de pagamento, mecanismo encontrado para minimizar esse problema. Já Britton e Gruber (2019) aplicam técnicas variadas para testar a hipótese de que o ECR inglês, que funciona na prática como uma alíquota marginal incremental ao Imposto de Renda, cause distorçôes na oferta de trabalho. Os resultados encontrados rejeitam fortemente tal hipótese.

O gráfico 1 mostra os resultados do nosso cenário preferencial considerando para ele o desenho em que cada alíquota incide sobre a renda bruta marginal, ou seja, sobre a faixa de renda a que estáo associadas. Optou-se por esse desenho para ilustrar o cenário preferencial porque seria o formato de mais fácil operacionalização no Brasil. Na hipótese de implementação de um ECR nacional em que o recolhimento dos pagamentos envolvesse os sistemas de escrituração fiscal digital mantidos pela RFB, adotar alíquotas marginais sobre as mesmas faixas de renda aplicadas para fins de cálculo do IRPF simplificaria a coleta, ainda que as alíquotas do ECR incidissem também sobre rendimentos não tributáveis aferíveis pela RFB. Não obstante, nada impede que, tal qual ocorre na Austrália, as alíquotas de um eventual ECR brasileiro incidissem sobre a renda bruta total dos egressos do ensino superior cujos estudos tenham sido financiados pelo Estado. Sob as mesmas alíquotas, se a cobrança fosse sobre a renda bruta total (ao invés de marginal), a taxa média de recuperaçáo seria maior e o tempo médio de amortizaçáo, menor (apêndice C). 
Mostra-se no gráfico 1, em separado para homens e mulheres e por cada decil de renda, tanto o número de anos necessários para zerarem a dívida (tempo médio de amortização) quanto o percentual do valor presente líquido (VPL) do empréstimo que conseguiriam pagar (taxa de recuperação de crédito). As linhas pontilhadas reportam o percentual que o governo conseguiria reaver (em VPL) do total dos desembolsos feitos para a coorte do exercício de simulação. Nas barras e nas linhas azuis claras estáo reportas as simulaçóes estáticas, isto é, as que usam dados de um só ano e que por isso mantêm cada pessoa no mesmo percentil de renda durante todos os anos em que amortiza o ECR. Nas barras e nas linhas azuis escuras estão reportadas as simulaçóes dinâmicas, que são as que partem do padrão de mobilidade de renda captado no painel para projetarem as mudanças de renda de cada pessoa ao longo do período amortizaçáo do ECR. Abaixo dos gráficos (A) e (B) estão informados, respectivamente, o tempo médio para zerar a dívida e o percentual médio de recuperação de crédito para toda a coorte (homens e mulheres conjuntamente), considerando o intervalo formado pela média obtida em cada uma das simulaçôes (estática e dinâmica).

Por um lado, as simulaçôes estáticas tendem a superestimar os subsídios, pois se apoiam em uma única observação no tempo e, por conseguinte, congelam as pessoas na mesma parte da distribuição de renda por toda a vida, ignorando qualquer mobilidade. Por outro, as simulaçóes dinâmicas tendem a subestimar os subsídios, pois captam mobilidade de renda entre dois anos consecutivos e extrapolam para todos os anos da análise o padrão observado nesses dois únicos anos observados, ignorando que para muitas pessoas as alternâncias na renda acabam sendo menos intensas no longo prazo do que porventura possam ter sido em um determinado momento de suas vidas. Assim, convém considerar os resultados das simulaçôes estática e dinâmica como um intervalo dentro do qual tende a se situar o patamar de subsídio implícito e o perfil de amortização de cada cenário.

O percentual de não pagamento no cenário ilustrado no gráfico 1 é menor do que a taxa de inadimplência de 61,8\% reportada em Almeida Júnior et al. (2019) para contratos do Fundo de Financiamento Estudantil (Fies) em fase de pagamento em março de 2018. Entre 55\% e 85\% dos recursos desembolsados para financiar estudantes seriam recuperados com faixas de cobrança alinhadas às do IRPF, juros equivalentes à TLP e percentual de vinculação da renda igual à metade da respectiva alíquota aplicada para fins de tributação da renda. O tempo necessário para pagar a dívida varia bastante a depender do gênero e do decil de renda, mas levaria, em média, de 26 a 30 anos. 
GRÁFICO 1

Número de anos até zerar dívida e percentual pago do VPL da dívida no cenário de ECR preferencial, com alíquotas incidentes sobre renda bruta marginal, homens e mulheres, por decil de renda e totais, simulação estática e simulação dinâmica - Brasil Por quanto tempo pagam?

$1 \mathrm{~A}-$ Homens

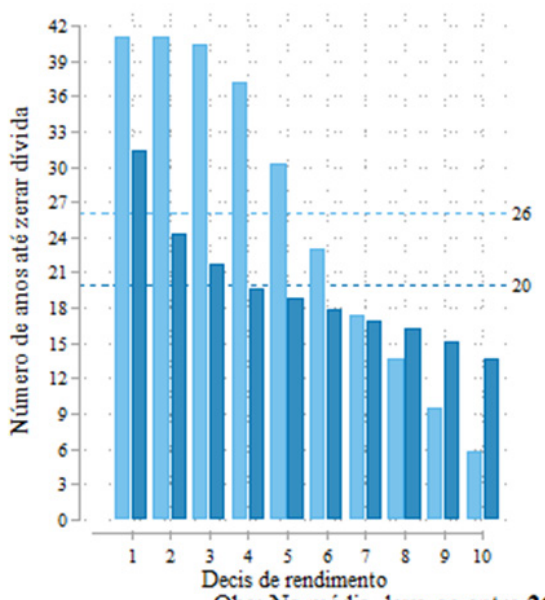

1B - Mulheres

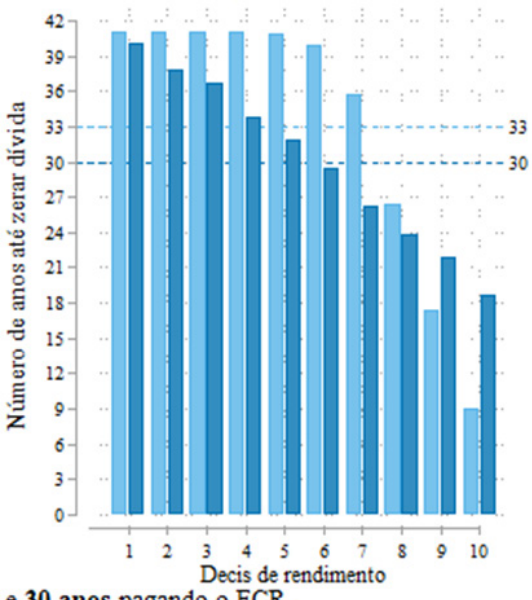

Que percentual do empréstimo conseguem pagar?

1C-Homens

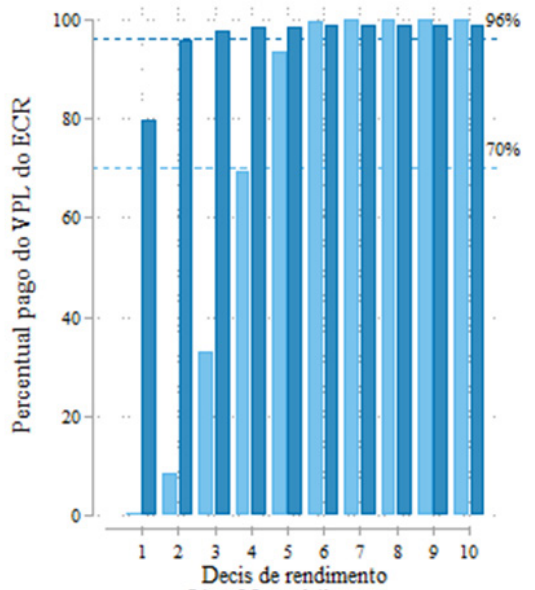

Obs: Na média, recupera-se entre $\mathbf{5 5 \%}$ e $\mathbf{8 5} \%$ do crédito concedido.
1D - Mulheres

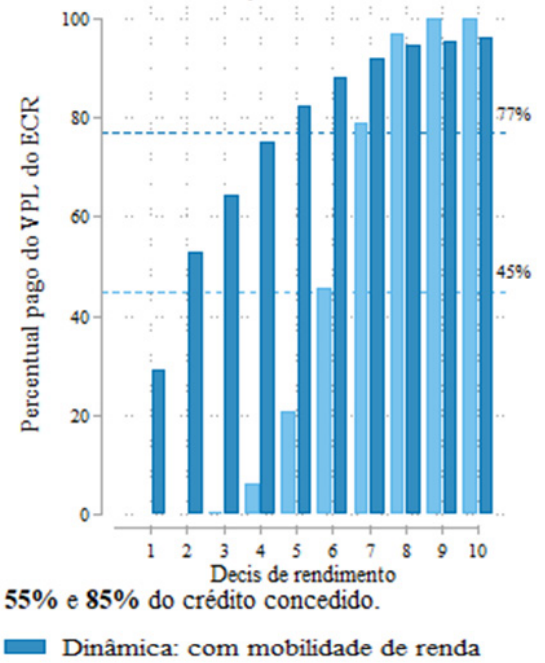


Vale ressaltar que o tempo médio necessário para zerarem suas dívidas é menor entre homens do que entre mulheres, em todos os decis de rendimento. Como reflexo disso, menos mulheres do que homes conseguem pagar integralmente seus empréstimos. $\mathrm{Na}$ média, homens levariam entre 20 e 26 anos pagando seu ECR, enquanto mulheres levariam entre 30 e 33 anos. A taxa de recuperação de crédito entre homens ficaria entre $70 \%$ e $96 \%$, contra um intervalo de $45 \%$ a $77 \%$ entre as mulheres. Esses resultados decerto refletem o fato de que a entrada em massa das mulheres no ensino superior e no mercado de trabalho nas últimas cinco décadas não se traduziu em igualdade de salários (Arretche, 2018), nem em igualdade de taxas de participação na força de trabalho (Medeiros e Pinheiro, 2018), embora valha ressaltar existirem desigualdades relativamente elevadas tanto entre homens quanto entre mulheres. É de se esperar que padrôes de renda e de amortização variem bastante também entre etnias e a depender de onde more a pessoa - as análises deste trabalho não exploraram essas diferenças.

\subsection{Juro real zero para todos é uma boa ideia em um ECR?}

Gráficos podem ajudar a ilustrar também porque subsídios à taxa de juros devem ser evitados em um ECR. O gráfico 2 mostra os resultados para o mesmo desenho ilustrado no gráfico 1, mas com uma única - porquanto fundamental - diferença: ao invés de corrigir o saldo devedor por uma taxa equivalente ao custo de financiamento do próprio governo, corrige-o pela inflação, isto é, aplica-se juro real zero. No desenho cujos resultados são mostrados no gráfico 1 , isso acontecia apenas durante a fase de estudos ou somente enquanto a renda permanecesse dentro da faixa de isenção durante a fase de amortização. Já no gráfico 2, o saldo devedor de toda e qualquer pessoa é corrigido sempre apenas pela inflação.

Comparando o gráfico 2 com o gráfico 1, percebe-se que uma política universal de juro real zero reduz todos os prazos médios de amortização, mas cai bastante o VPL dos pagamentos coletados. ${ }^{16}$ As taxas de recuperação de crédito ficariam entre 44\% e 64\% (no gráfico 1 eram entre 55\% e 85\%). Tamanha perda justifica a incorporação de juros reais positivos, pois fariam egressos com bom padrão de renda pagarem $100 \%$ do VPL de seu financiamento (ou até um pouco mais, a depender do desenho do

16. A taxa de juros no ECR dado gráfico 2 não é mais a TLP, mas esta segue sendo utilizada como taxa de desconto para fins de cálculo do VPL dos pagamentos futuros. Também segue a mesma a suposição quanto à variação média dos rendimentos brutos ao longo dos anos. 
programa), sem que isso ensejasse para ninguém, em nenhum momento, encargos financeiros capazes de comprometer a saúde financeira sua ou de sua família. Restringir a política de juro real zero ao período de estudos e para os egressos com renda dentro da faixa de isenção limita o crescimento do saldo devedor em períodos de não pagamento, sem que isso signifique um custo fiscal elevado. ${ }^{17}$

Sem universalizar juro real zero e seguindo parâmetros nos moldes dos sugeridos na tabela 3, abstrai-se das simulações que um ECR tenderia a ter um desempenho fiscal bastante razoável no Brasil. Comparações internacionais reforçam conclusão neste sentido. Shen e Ziderman (2009) levantam dados de 44 programas governamentais de crédito educacional então em operação em 39 países e mostram que em mais de 40\% deles a taxa de recuperação de crédito não chega a 40\% do VPL dos desembolsos. Mesmo programas com desenho de ECR são eivados de substanciais subsídios implícitos (que nada mais são do que o complemento da taxa de recuperação de crédito): 12,2\% na Inglaterra, 25,7\% na Austrália e 41,1\% na Nova Zelândia. ${ }^{18}$

17. Retirar o benefício do juro real zero durante a fase de estudos e enquanto a renda estivesse dentro da faixa de isenção renderia ao governo até 2 pontos percentuais (p.p.) a mais nas taxas de recuperação de crédito mostradas no gráfico 1, segundo simulações feitas, mas não reportadas neste estudo.

18. Subsídios implícitos em um ECR devem-se a taxas de juros abaixo do custo de financiamento do governo ou a montantes de dívida prescrita. Três são os programas governamentais universais de ECR mais discutidos na literatura: o da Nova Zelândia, o da Austrália e o da Inglaterra (Britton, Van der Erve e Higgins, 2019). 0 primeiro é o de pior desempenho entre os três, pois, em regra, não incidem sequer juros nominais sobre a dívida. 0 da Austrália corrige os saldos devedores só pela inflação. 0 ECR inglês é o que cobra juros maiores, mas é possível que tenham crescido seus subsídios desde o levantamento feito por Shen e Ziderman (2009). Isto porque reformas implementadas em 2012 elevaram bastante o montante que estudantes podem tomar emprestado e aumentaram ainda mais as taxas de juros. Desde então, poucos ingleses conseguem pagar a totalidade de sua dívida antes dos trinta anos de prazo máximo de amortização (após os quais prescreve a dívida porventura remanescente). Tanto na Austrália quanto na Nova Zelândia a dívida do ECR só prescreve em caso de morte do devedor. 
GRÁFICO 2

Número de anos até zerar a dívida e percentual pago do VPL da dívida quando o saldo devedor do ECR do gráfico 1 é ajustado só pela inflação, homens e mulheres, por decil de renda e totais, simulação estática e simulação dinâmica - Brasil

Por quanto tempo pagam?

$2 \mathrm{~A}$ - Homens

$2 \mathrm{~B}$ - Mulheres
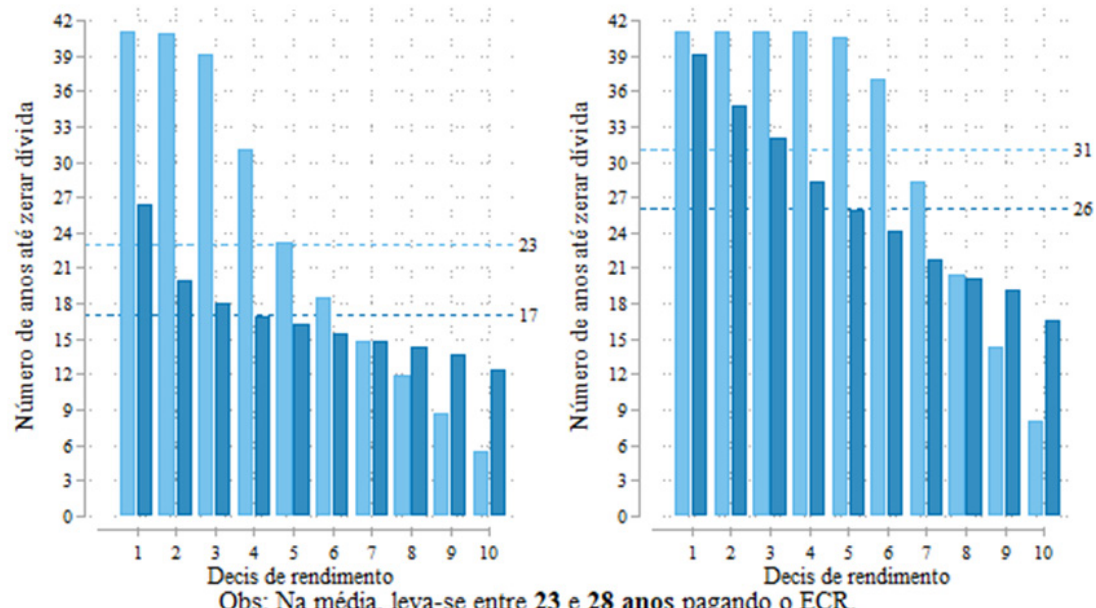

Obs: Na média, leva-se entre 23 e 28 anos pagando o ECR.

Que percentual do empréstimo conseguem pagar?

$2 \mathrm{C}$ - Homens

$2 D$ - Mulheres
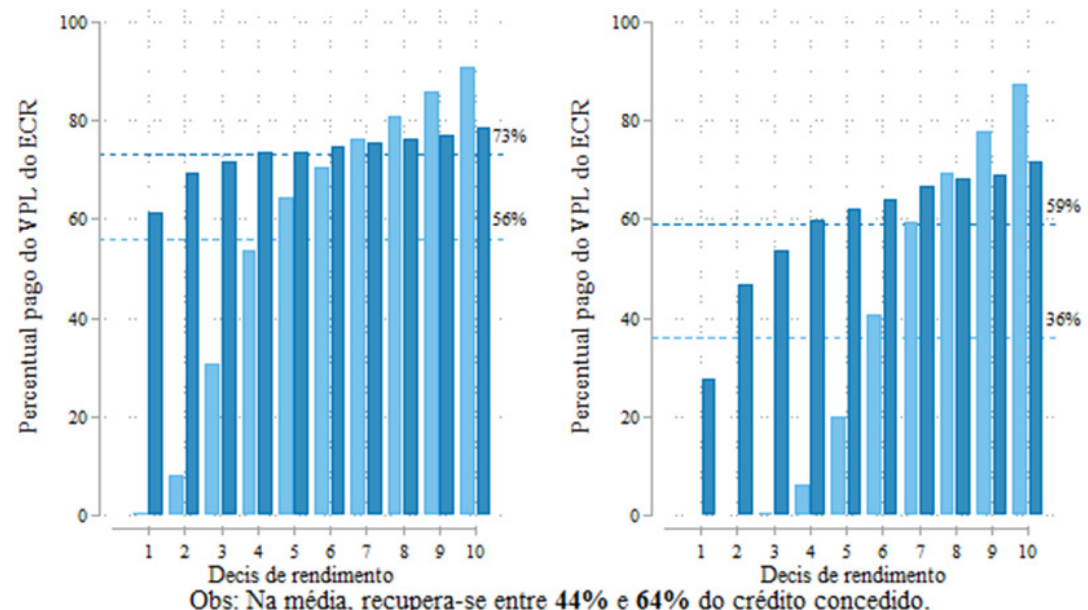

Obs: Na média, recupera-se entre $44 \%$ e $64 \%$ do crédito concedido.

Estática: sem mobilidade de renda

Dinâmica: com mobilidade de renda 
Sob os pressupostos assumidos, o ECR ilustrado no gráfico 1 é muito superior ao ECR ilustrado no gráfico 2 e mostra-se mais eficiente que ECRs de outros países. Nosso cenário preferencial (gráfico 1) acarretaria subsídios implícitos da ordem de $15 \%$ a $45 \%$, muito menores do que os decorrentes do cenário de juro real zero para todos (gráfico 2), que foram estimados entre $36 \%$ e $56 \%$. O cenário preferencial tenderia a impor ao contribuinte brasileiro uma conta compatível com a verificada em modelos análogos em operação alhures. Tal qual os ECRs da Inglaterra, da Austrália e da Nova Zelândia, o ECR do gráfico 1 protegeria quem náo pode pagar, mas com um diferencial a torná-lo mais eficiente que o modelo em operação nesses outros países: ao limitar a concessão de juro zero a situaçôes bem específicas, os parâmetros da tabela 3 concentrariam os subsídios na prescrição da dívida remanescente quando a idade de 65 anos é alcançada - o que beneficia os mais pobres.

Vale notar ainda que todas as taxas de vinculação de renda consideradas para o cenário preferencial de ECR são inferiores a $18 \%$ do rendimento bruto, limite que a literatura internacional costuma indicar para que os pagamentos de um ECR não comprometam o bem-estar financeiro de seus devedores e suas famílias (Nascimento, 2018). É possível que haja espaço para discutir alíquotas maiores, em especial porque o ECR deste nosso cenário preferencial pressupóe cobrança sobre o rendimento marginal, não sobre o rendimento total. Ressalte-se, porém, que esse limite da literatura é meramente ad hoc e não há ainda estimativas considerando especificidades do contexto brasileiro.

\subsection{Qual a justificativa para haver faixa de isenção em um ECR?}

O potencial de arrecadação de um desenho de ECR nos moldes do ilustrado no gráfico 1 permanece superior ao de uma política de juro zero mesmo se esta aplicasse uma alíquota única de $20 \%$ e não previsse nenhuma faixa de isenção. Tal desenho é possível sob a Lei $\mathrm{n}^{\mathrm{o}}$ 13.530/2017 (Lei do Novo Fies), que expressamente coloca 20\% como limite máximo de vinculação da renda ou proventos mensais brutos do estudante financiado pelo Fies. ${ }^{19}$ Os resultados da simulação de tal desenho são apresentados no gráfico 3 e contrastados com os resultados apresentados no gráfico 4, que retira o benefício do juro

19. Embora a Resolução no 5/2017, do Comitê Gestor do Fies (CG-Fies), tenha estabelecido 13\% como percentual máximo de vinculação da renda disponível do egresso para os pagamentos dos contratos do Fies assinados depois da promulgação da Lei no 13.530/2017. 
real zero do desenho baseado na Lei do Novo Fies. Isto aumenta a arrecadação, porém às custas de recolher pagamentos até de egressos de baixa renda. Em termos de equidade, melhor haver uma faixa de isenção.

O gráfico 3 mostra que, com uma política de juros reais zero, a implementação de um ECR com uma única e alta alíquota de reembolso aplicado a todos os devedores tenderia a reduzir a taxa de recuperação de crédito, em comparação ao cenário preferencial ilustrados no gráfico 1. Isto significaria maior custo fiscal no longo prazo. Tal custo fiscal seria eliminado quase que na totalidade ${ }^{20}$ se os juros fossem equivalentes à TLP, como ilustra a gráfico 4. Ocorre que um e outro dos cenários ilustrados nos gráficos 3 e 4 iriam impor aos mais pobres elevados encargos, pois o pagamento seria recolhido mesmo de quem ganhasse baixos proventos (por exemplo, um salário mínimo). Nos cenários mostrados anteriormente, havia uma faixa de isenção (a mesma vigente para o IRPF) que alcançava rendimentos mensais médios mais do que duas vezes superiores ao salário mínimo vigente em 2017.

Em suma, um ECR que vinculasse $20 \%$ da renda de todos os mutuários aos pagamentos do financiamento estudantil comprometeria o bem-estar dos egressos de baixa renda, ainda que a introduçáo de juros no nível do custo de financiamento do governo pudesse aproximá-lo de um programa fiscalmente neutro. Se os juros cobrados fossem suficientes apenas para corrigir os saldos devedores pela inflação, esse desenho do ECR ainda por cima faria com que nem mesmo os mais ricos pagassem de volta a totalidade do VPL de seus empréstimos.

20. A taxa de recuperação de crédito ficaria em um patamar entre $88 \%$ e $100 \%$ do VPL dos desembolsos do ECR. 


\section{GRÁFICO 3}

Número de anos até zerar a dívida e percentual pago do VPL da dívida quando não há faixa de isenção nem sobretaxas adicionadas aos montantes iniciais dos empréstimos e incide alíquota única de $20 \%$ sobre a renda bruta total, com o saldo devedor do ECR ajustado pela inflação, homens e mulheres, por decil de renda e totais, simulação estática e simulação dinâmica - Brasil

Por quanto tempo pagam?

$3 \mathrm{~A}-$ Homens

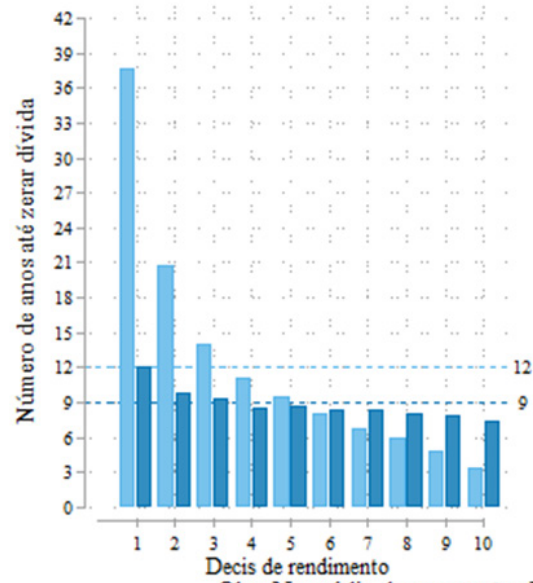

Obs: Na média, leva-se entre 11 e 16 anos pagando o ECR.
3B - Mulheres

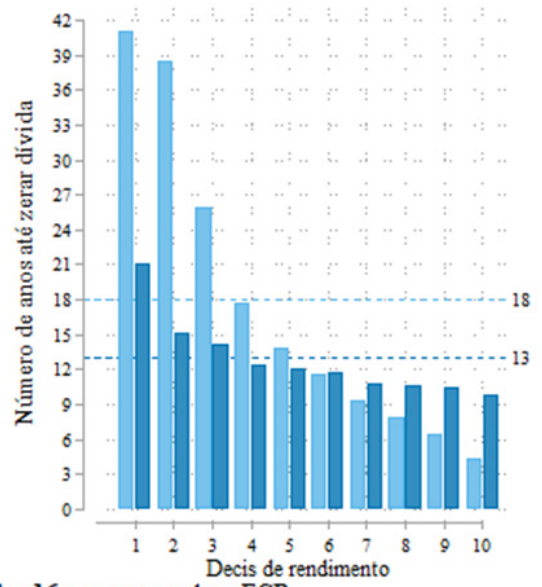

Que percentual do empréstimo conseguem pagar?

$3 \mathrm{C}-$ Homens

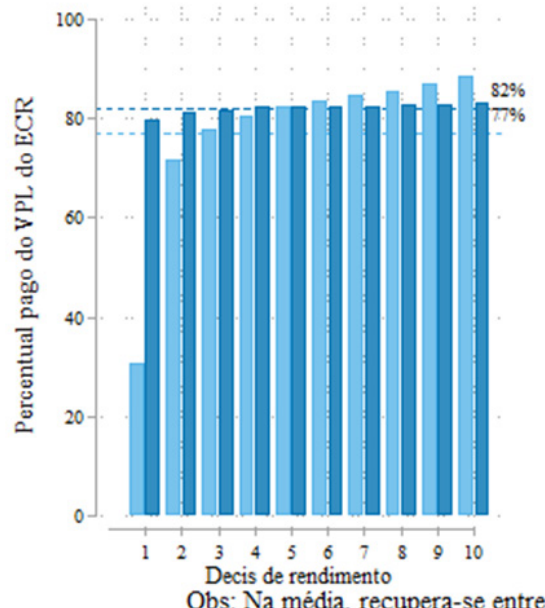

Obs: Na média, recupera-se entre $\mathbf{7 2} \%$ e $80 \%$ do crédito concedido.
3D - Mulheres

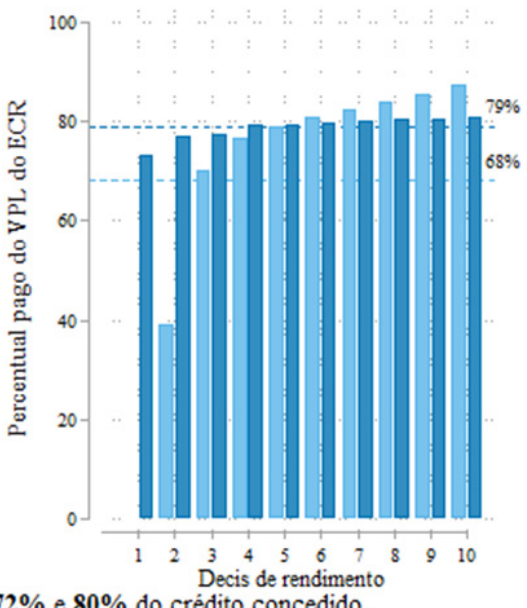

Dinâmica: com mobilidade de renda

Elaboração do autor. 
GRÁFICO 4

Número de anos até zerar a dívida e percentual pago do VPL da dívida quando não há faixa de isenção nem sobretaxas adicionadas aos montantes iniciais dos empréstimos e incide alíquota única de $20 \%$ sobre a renda bruta total, com o saldo devedor do ECR ajustado pela TLP, homens e mulheres, por decil de renda e totais, simulação estática e simulação dinâmica - Brasil

Por quanto tempo pagam?

$4 \mathrm{~A}$ - Homens

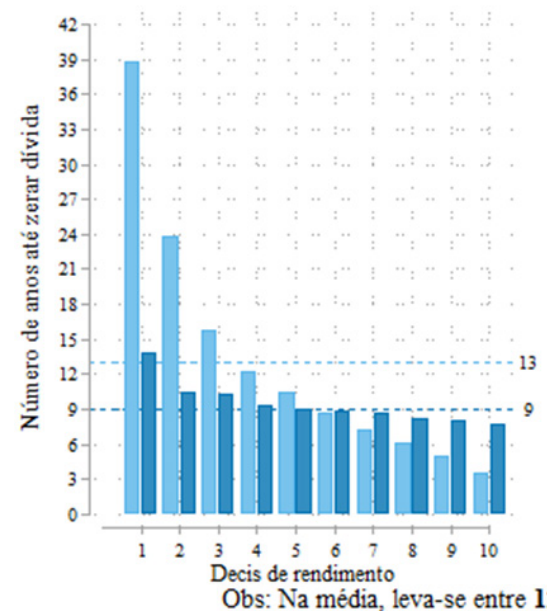

4B - Mulheres

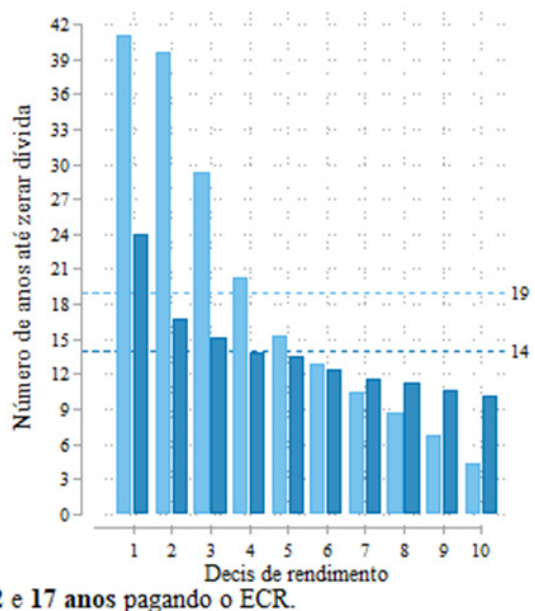

Que percentual do empréstimo conseguem pagar?

4C - Homens

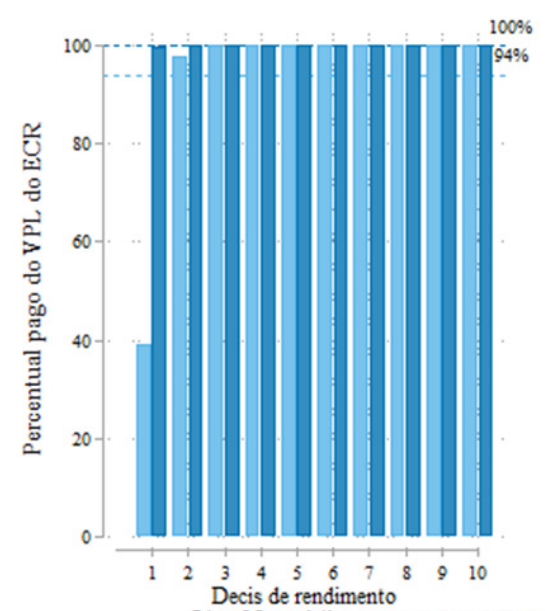

4D - Mulheres

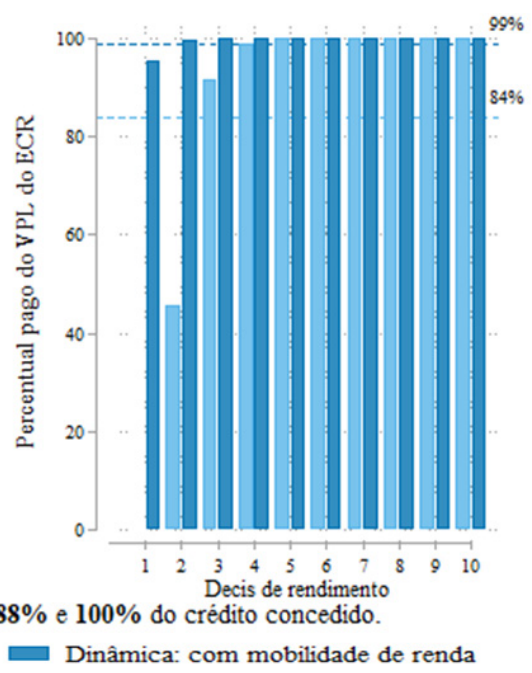

Elaboração do autor. 


\subsection{Recolher ECR apenas em folha de pagamento reduz muito a base pagadores}

Seja qual for o cenário considerado, vale ressaltar que as taxas de recuperação de crédito simuladas pressupóem recolhimento de pagamentos vinculados a todas as fontes de renda informadas pelas pessoas com diploma de nível superior da amostra. A efetividade do recolhimento do percentual incidente sobre lucros, dividendos, pró-labore e rendimentos de trabalhadores autônomos é táo importante quanto o recolhimento do percentual incidente sobre a remuneração de trabalhadores empregados em postos formais de trabalho.

A gráfico 5 mostra a importância de ir além a um mecanismo de desconto em folha de pagamento para recolher prestaçóes de um ECR. Utilizando dados da PNAD Contínua 2017, o gráfico 5 classifica como alcançáveis por desconto em folha os indivíduos com emprego formal e como rastreáveis pela Receita Federal não apenas os indivíduos formalmente empregados, mas também aqueles que haviam declarado contribuir para a seguridade social ou para algum plano de previdência e aqueles que haviam se declarado sócios de firmas com registro no Cadastro Nacional de Pessoa Jurídica (CNPJ). Os diagramas plotados no gráfico 5 são apenas uma aproximação. É possível que a RFB tenha condições de alcançar proporções ainda maiores de indivíduos do que os ali representados, pois há evidências empíricas de subnotificação de renda (particularmente lucros) em pesquisas domiciliares no Brasil (Medeiros, Souza e Castro, 2015). 
GRÁFICO 5

Estimativa das proporções de pessoas adultas com rendimentos mensuráveis rastreáveis pela RFB e por sistemas de desconto em folha de pagamentos, homens e mulheres, por faixa etária e em separado para quem tem nível superior e quem não tem - Brasil (2017) (Em \% de pessoas entre 25 e 64 anos de idade com renda aferível)

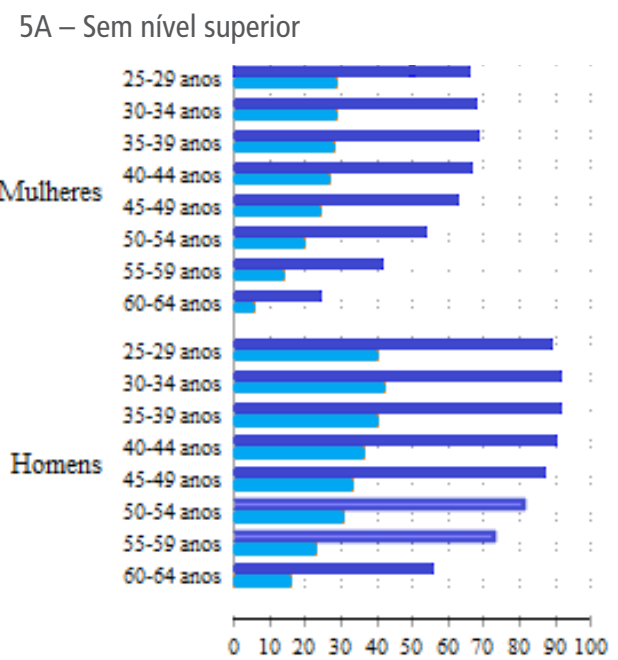

5B - Com nível superior

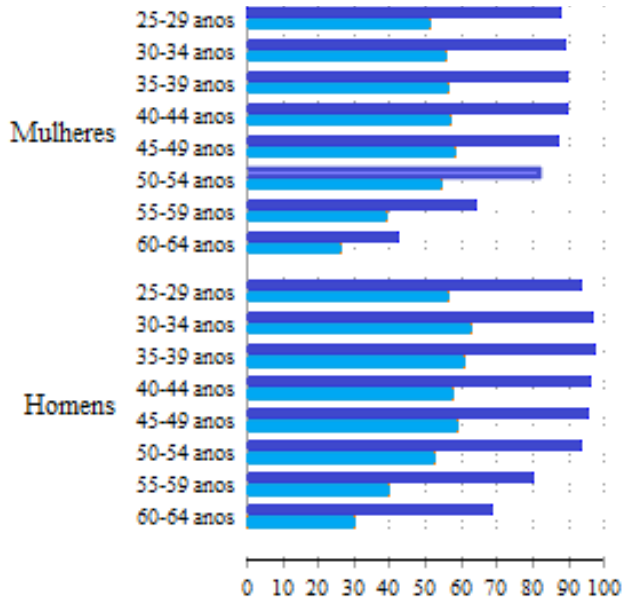

Fonte: PNAD Contínua 2017

Rastreáveis pela Receita Federal

Elaboração do autor.

Alcançáveis por desconto em folha

O gráfico 5 traz duas contribuições principais: i) ilustra que a economia informal é um problema relativamente pequeno para coletar pagamentos de um ECR de pessoas com diploma de nível superior no Brasil, uma vez que mais de $90 \%$ dos homens até 54 anos e quase $90 \%$ das mulheres até 49 anos reportam fontes de rendimentos rastreáveis pela RFB; e ii) mostra que o envolvimento total da RFB na coleta dos pagamentos aumentaria substancialmente o número de pagadores de um ECR no Brasil, em comparação com a alternativa de colocar em operação, para o recolhimento dos pagamentos do financiamento vinculado à renda, apenas ferramentas de desconto em folha de pagamentos. 


\section{CONCLUSÕES, RECOMENDAÇÕES DE POLÍTICA E CONSIDERAÇÕES FINAIS}

Como toda política pública, o desenho de um ECR depende de escolhas que geram ganhos e perdas para diferentes atores. Por um lado, generosos ECRs - em que os pagamentos são cobrados durante um prazo relativamente curto, comprometem percentual muito baixo da renda e sobre os quais incidem juros muito subsidiados - geram subsídios públicos elevados, parte dos quais capturados por quem poderia pagar $100 \%$ do valor presente de sua dívida. Por outro, ECRs fiscalmente sustentáveis impóem pagamento de $100 \%$ ou eventualmente até de mais de $100 \%$ do VPL da dívida dos egressos de alta renda, ao mesmo tempo em que suspendem os pagamentos de quem não tem renda suficiente para pagá-lo, ajustando o período de amortização à capacidade de pagamento da pessoa. Isto aproxima o empréstimo, para os egressos que não conseguem liquidá-lo com relativa rapidez, mais de um programa de refinanciamento automático do que de um empréstimo tradicional - possivelmente também com um mecanismo de prescrição da dívida, que nada mais é do que um eventual perdáo por decurso de tempo.

Dado que os pagamentos de um ECR são vinculados à renda, sua implementação pode aproximá-lo de um tributo. Um empréstimo é mais transparente do que um tributo para financiar formaçáo acadêmica e profissional, pois um saldo devedor previamente conhecido expóe mais claramente quanto cada pessoa teria que pagar. É também conceitualmente mais lógico, dado que a adoção de um tributo implica a ideia contraintuitiva de taxar capital humano. Ademais, diferenciar montantes máximos de pagamento de acordo com o custo do investimento no Estado na formação da pessoa elimina situaçóes em que alunos oriundos de famílias de baixa renda matriculados em cursos de baixo custo que venham a se tornar profissionais bem remunerados acabem por pagar muito mais do que deveriam, beneficiando, ao final, também filhos de famílias ricas que escolham cursos caros, mas acabem não dispondo de renda própria alta depois de formados. Os problemas próprios de um tributo do graduado podem ser contornados se o caráter de obrigação tributária dos pagamentos vinculados à renda for compatível com desenhos de ECRs ou mesmo de ISAs. No contexto institucional brasileiro, uma contribuição especial poderia ser o caminho para justificar a atuação da RFB na administração da cobrança, algo essencial para o sucesso da política, sem abrir mão de arranjos mais próximos às principais recomendaçóes da literatura de financiamento estudantil e às melhores práticas internacionais. 
Há precedentes exitosos nessa linha no Brasil, como o modelo da contribuição patronal que mantém o Sistema $S$ e o modelo do AFRMM que mantém o Fundo da Marinha Mercante (FMM). No contexto deste trabalho, poderia consistir, por exemplo, em um sistema centrado em uma agência reguladora ou em uma entidade paraestatal, à qual caberia gerenciar a receita arrecadada por uma contribuição especial recolhida pela RFB. Pode-se pensar como fato gerador dessa contribuição a obtenção de um financiamento estudantil em uma das modalidades previstas em lei - modalidades essas na forma de ECRs ou de ISAs, oferecidas ora pelo Estado (para financiar, por exemplo, estudos em nível de graduação ou de pós-graduação, em instituiçôes públicas ou privadas), ora por entidades de intermediação financeira (bancos públicos e privados, cooperativas de crédito e afins), ora por instituiçóes de ensino (algumas das quais já operam programas próprios de financiamento estudantil), ora até mesmo por fundaçôes e entidades sem fins lucrativos (que poderiam ver nos ECRs e nos ISAs formas de expandir seus programas de bolsa de estudo). Esta proposição remeteria a um sistema nacional de financiamento estudantil em que ECRs e ISAs coexistiriam, seriam atraentes em alguns nichos para a iniciativa privada e viabilizariam atuação sustentável do Estado nas situaçóes em que o financiamento público se faz necessário. Transformar os pagamentos em uma obrigação tributária seria a forma de envolver a RFB na administração da cobrança, mas, em termos práticos, haveria um sistema de ECRs e de ISAs regulado em lei e por órgão regulador instituído para essa finalidade, com entidades diversas credenciadas a conceder as modalidades de financiamento estudantil previstos na legislação, inclusive com recursos próprios.

Em outros formatos híbridos propostos na literatura (e ainda não testados na prática), os pagamentos vinculados à renda não necessariamente são uma obrigação tributária, mas tampouco estão diretamente relacionados a um saldo devedor (como seria no caso de um ECR) ou ao retorno de um investimento (como seria no caso de um contrato de capital humano). Este é o caso do desenho de um modelo proposto para os Estados Unidos e analisado por Chingos (2016). ${ }^{21}$ Consistia basicamente em uma linha de crédito cujo pagamento comprometeria $1 \%$ da renda pessoal para cada US\$ 10 mil financiados, com recolhimento em folha junto com o pagamento à Seguridade Social e cessando apenas se a soma dos pagamentos feitos alcançasse 1,75 vezes o valor

21. Desenho esse que nunca chegou a ser implementado, mas, como já dito anteriormente, compunha a plataforma de campanha de um pré-candidato às eleições de 2016 para Presidência dos Estados Unidos. 
originalmente financiado ou se antes disso fossem transcorridos 25 anos. Ressalte-se, porém, que mesmo quando adotado com características bem próprias de um empréstimo (como, por exemplo, nos casos dos ECRs em operaçáo na Austrália e na Inglaterra), o envolvimento do órgão de administração tributária na coleta dos pagamentos já lhe confere características formais de um tributo.

A forma como a política é apresentada não é uma questão menor, como mostram alguns experimentos recentes conduzidos em outros países. Em uma série desses experimentos, feitos com estudantes do Chile, da Colômbia e do México, Caetano, Palacios e Patrinos (2019) mostram que mesmo um ECR bem desenhado pode ser rechaçado em prol de alternativas idênticas ou até mesmo mais onerosas de financiamento, quando a alternativa ao ECR não é categorizada como empréstimo e pessoas avessas a dívidas são colocadas diante da escolha. Em outra série recente de experimentos, Lergetporer e Woessmann (2019) mostram que, entre eleitores alemães, informação que leve a um adequado entendimento do caráter de seguro que exercem os pagamentos vinculados à renda é capaz de transformar uma maioria em prol de gratuidade no ensino superior em uma maioria em prol de uma política de financiamento compartilhado baseada em pagamentos vinculados à renda. Percebe-se, pois, que comunicar bem a natureza e os parâmetros de um financiamento com pagamentos vinculados à renda é crítico para a devida compreensão, por parte dos próprios estudantes e da população em geral, do caráter meramente contábil que esse tipo de financiamento confere à dívida estudantil de quem não aufere renda suficiente ao longo da vida para conseguir pagá-la integralmente.

Sem entrar no mérito acerca de como comunicar ao grande público o funcionamento e as variaçôes de formato de financiamentos com pagamentos vinculados à renda, as simulaçóes apresentadas neste trabalho ativeram-se a desenhos de ECR propriamente ditos. Há benefícios e custos envolvendo cada opção de desenho simulada. As simulaçôes são particularmente úteis em mostrar que em um ECR os subsídios podem ser concentrados nos mais pobres. Também são úteis em expor o custo fiscal de distribuir subsídios indiscriminadamente por meio de uma política de crédito educacional contingente à renda. Ilustram bem, portanto, as potenciais implicaçóes em termos de recuperação de crédito e de capacidade de pagamento quando são alterados parâmetros como taxas de juros e faixas e percentuais de comprometimento da renda para pagamento. 
Há também limitações nas simulações apresentadas, algumas decorrentes dos próprios pressupostos assumidos. Devem ser tomados com especial cautela os pressupostos concernentes à evolução real da renda ao longo dos anos (aumento médio de 1\% a.a.) e ao comportamento da taxa oficial de inflação (mantida estável em 3,75\% a.a.) e do custo de oportunidade dos recursos emprestados (definido neste trabalho como sendo de 2,8\% a.a.). As simulaçóes adicionais reportadas no apêndice $\mathrm{C}$ ajudam a perceber o quanto os pressupostos assumidos afetam os resultados das simulaçóes. Outra limitação é que o método utilizado é incapaz de capturar as possíveis respostas comportamentais dos agentes se colocados diante de cada desenho alternativo para a política de financiamento estudantil.

A decisão final dos parâmetros de um eventual programa público de financiamento refletiria, acima de tudo, escolhas políticas. Vale destacar, entretanto, que os cenários simulados invariavelmente trazem perspectivas de reembolso semelhantes (nos cenários mais pessimistas reportados no apêndice $\mathrm{C}$ ) ou até muito melhores (nos cenários mais otimistas reportados no apêndice $\mathrm{C}$ ) do que as estimativas oficiais de recuperação do crédito reportadas em Almeida Júnior et al. (2019) para os contratos que estavam em fase de pagamento pelo Fies em março de 2018.

Fatores endógenos e exógenos concorrem para que sejam factíveis cenários como os apresentados neste trabalho.

Os fatores exógenos são as condiçốes externas e alheias à discricionariedade do formulador da política de financiamento, como estabilização econômica, condiçôes do mercado de trabalho e segurança jurídica. Em todas as simulaçôes apresentadas assumiu-se um bom nível de segurança jurídica. Os pressupostos assumidos em relação à evolução real dos rendimentos dos egressos, à taxa real de desconto e à inflação tinham por objetivo manter constantes, para cada cenário simulado, as condiçôes macroeconômicas e de mercado de trabalho. Desses, o comportamento da inflação é o que menos tenderia a afetar os resultados do ECR, pois, excetuando-se cenários de hiperinflação, seria a variável externa mais fácil de internalizar no desenho da política, bastando para isso estabelecer um índice oficial de inflação como patamar mínimo para a taxa de juros aplicada aos financiamentos. 
Os fatores endógenos são os que estariam mais diretamente ao alcance do formulador da política de financiamento. Três deles merecem destaque para o bom funcionamento de um ECR.

O primeiro diz respeito aos mecanismos de recolhimento dos pagamentos vinculados à renda. No contexto do Brasil, em que a própria legislaçáo incentiva profissionais liberais e autônomos a trabalharem transmutados de firmas individuais para pagar menos Imposto de Renda, se faria necessário o envolvimento de todos os mecanismos possíveis de desconto na fonte para otimizar a coleta dos pagamentos do ECR. Os pagamentos vinculados à renda, portanto, deveriam incidir sobre todas as fontes de renda aferíveis pela RFB.

$\mathrm{O}$ segundo diz respeito às regras de exigibilidade dos próprios pagamentos, a fim de garantir o caráter de seguro do ECR - que não deve ser confundido com um mero crédito consignado. Para que seja efetivamente um ECR, é necessário que não haja exigência de pagamentos mínimos não-vinculados à renda (como permanece havendo no Fies, mesmo sob as regras da Lei no 13.530/2017) e, como proteção adicional aos mais pobres, é desejável alguma faixa de isenção e um mecanismo de prescrição da dívida porventura remanescente ao final da vida ou transcorrido longo período.

O terceiro fator endógeno relevante é a taxa de juros incidente sobre os montantes emprestados. Sua estipulação depende de escolhas políticas, tocantes principalmente ao nível de subsídio considerado aceitável nesse tipo de política pública em cada momento histórico. Não obstante, vale ressaltar que uma taxa de juros muito distante do custo de financiamento do governo encareceria de tal maneira o programa de crédito educacional que, no limite, seria mais transparente e quiçá até mais barato optar logo por um programa de bolsas ao invés de oferecer empréstimos estudantis e arcar com toda uma estrutura administrativa para monitorar dívidas e recolher pagamentos (Nascimento, 2016).

Assim sendo, é importante, tanto para a sustentabilidade fiscal do programa quanto para a promoção da justiça social, que o desenho de financiamento estudantil adotado seja capaz de fazer com que egressos com bom padráo de renda acabem pagando 100\% ou até um pouco mais do custo direto de sua formação (Barr et al., 2019). Quando o formato adotado é de um empréstimo, isto significa que sobre o saldo devedor acumulado no momento do encerramento da matrícula sejam cobradas taxas de juros no patamar 
da TLP, da taxa básica de juros da economia, da taxa paga para remunerar títulos públicos de longo prazo, ou de alguma outra medida que minimamente refletisse o custo de financiamento do próprio governo.

Um ECR com essas características subsidiaria apenas quem não teria renda suficiente ao longo da vida para pagar sua dívida e minimizaria o custo fiscal do crédito educacional dado a quem estuda em cursos privados, além de permitir introduzir uma contribuiçáo financeira dos egressos das públicas. É um caminho para tornar o Fies sustentável e para viabilizar novos recursos para o sistema público de ensino superior, em ambos os casos sem comprometer em demasia a renda de quem precisa de financiamento público para cursar uma graduação.

\section{REFERÊNCIAS}

ALMEIDA JÚNIOR, M. F. et al. A reestruturação do Fies. In: NASCIMENTO, P. M. (Org.). Financiamentos com pagamentos vinculados à renda futura: a produção do Ipea até 2018. Brasília: Ipea, 2019. p. 303-310.

ARRETCHE, M. (Org.). Paths of inequality in Brazil: a half-century of changes. 1st ed. Nova York: Springer, 2018.

BAIR, S.; COOPER, P. The future of income-share agreements. Nova York: Manhattan Institute, Mar. 2019. Disponível em: <https://bit.ly/2J4oB6r>. Acesso em: 17 abr. 2019.

BARALDI, A. O que é Income Share Agreement (ISA)? Medium, 22 Jan. 2020. Disponível em: <https://bit.ly/3dcrPPZ>. Acesso em: 28 maio 2020.

BARR, N. Economics of the Welfare State. 1st ed. Oxford: Oxford University Press, 2001.

BARR, N. et al. The US college loan system: lessons from Australia and England. Economics of education review, v. 71, p. 32-48, Aug. 2019.

BELTRÃO, K. I.; ALVES, J. E. D. A reversão do hiato de gênero na educaçâo brasileira no século XX. Cadernos de pesquisa, v. 39, n. 136, p. 125-156, 2009.

BONHOMME, S.; ROBIN, J.-M. Assessing the equalizing force of mobility using short panels: France, 1990-2000. The review of economic studies, v. 76, n. 1, p. 63-92, 2009.

BORNSTEIN, D. A way to pay for college, with dividends. 2011. Disponível em: <https:// nyti.ms/2s1Dyef>. Accesso em: 21 May 2018. 
BRITTON, J.; GRUBER, J. Do income contingent student loan programs distort earnings? Cambridge: National Bureau of Economic Research, 2019. (Texto para Discussão n. 25.822). Disponível em: <https://bit.ly/2MOOedN>. Acesso em: 13 maio 2019.

BRITTON, J.; SHEPHARD, N.; VAN DER ERVE, L. Econometrics of valuing income contingent student loans using administrative data: groups of English students. Londres: Institute for Fiscal Studies, 2019. (Texto para Discussão, n. 13.953). Disponível em: <https:// bit.ly/3oDnxGp>. Acesso em: 21 maio 2019.

BRITTON, J.; VAN DER ERVE, L.; HIGGINS, T. Income contingent student loan design: Lessons from around the world. Economics of education review, v. 71, p. 65-82, ago. 2019.

CAETANO, G.; PALACIOS, M.; PATRINOS, H. A. Measuring aversion to debt: An experiment among student loan candidates. Journal of family and economic issues, v. 40, n. 1 , p. $117-131,2019$.

CHAPMAN, B. The economics and public policy of student loans: Lessons for Brazil. In: CONFERENCIA INTERNACIONAL SOBRE FINANCIAMENTO VINCULADO À RENDA: ALTERNATIVAS PARA O ENSINO SUPERIOR E OUTRAS ÁREAS DE POLÍTICA PÚBLICA. Anais... Brasília, 10-12 jul. 2019. Disponível em: <https://bit.ly/2kPdrXZ>. Acesso em: 6 set. 2019.

CHAPMAN, B.; DOAN, D. Financiamento do ensino superior: questóes conceituais e a experiência internacional. In: NASCIMENTO, P. M. (Org.). Financiamentos com pagamentos vinculados à renda futura: a produção do Ipea até 2018. Brasília: Ipea, 2019a.

CHAPMAN, B; DOAN, D. Introduction to the special issue "higher education financing: student loans". Economics of education review, v. 71, p. 1-6, Aug. 2019 b.

CHAPMAN, B.; LEIGH, A. Do very high tax rates induce bunching? Implications for the design of income contingent loan schemes. Economic record, v. 85, n. 270, p. 276-289, 2009.

CHAPMAN, B.; LOUNKAEW, K. An analysis of Stafford loan repayment burdens. Economics of education review, v. 45, p. 89-102, Apr. 2015.

CHAPMAN, B.; HIGGINS, T.; STIGLITZ, J. (Orgs.) Income contingent loans: theory, practice and prospects. London: Palgrave Macmillan, 2014.

CHINGOS, M. M. Jeb Bush's student loan plan should outlive his campaign. Evidence speaks reports, Washington, v. 1, n. 10, 2016.

DEARDEN, L. Designing sustainable income contingent loans. In: CONFERENCIA INTERNACIONAL SOBRE FINANCIAMENTO VINCULADO À RENDA: ALTERNATIVAS PARA O ENSINO SUPERIOR E OUTRAS ÁREAS DE POLÍTICA PÚBLICA. Anais... Brasília, 10-12 jul. 2019a. Disponível em: <https://bit.ly/2lelOwH>. Acesso em: 6 set. 2019. 
Evaluating and designing student loan systems: an overview of empirical approaches. Economics of education review, v. 71, p. 49-64, Aug. 2019 b.

DEARDEN, L.; NASCIMENTO, P. M. Modelling alternative student loan schemes for Brazil. Economics of education review, v. 71, p. 83-94, Aug. 2019.

DYNARSKI, S. An economist's perspective on student loans in the United States. Munique, Alemanha: CESifo, out. 2015. (Texto para Discussão, n 5.579). Disponível em: <https:// bit.ly/2YGmYRm>. Acesso em: 10 dez. 2015.

ESPINOZA, R.; URZÚA, S. La inconveniencia de un impuesto a los graduados para financiar una educación superior gratuita. Economía y política, v. 2, n. 2, p. 77-106, 2015.

FERNANDES, R. C.; CAMPOLINA, B.; SILVEIRA, F. G. The distributive impact of income taxes in Brazil. Brasília: IPC-IG, 2018.

FRIEDMAN, M. The role of government in education. In: SOLO, R. A. (Ed.). Economics and the public interest. New Brunswick: Rutgers University Press, 1955. p. 123-144.

HIGGINS, T.; SINNING, M. Modelling income dynamics for public policy design: an application to income contingent student loans. Economics of education review, v. 37, p. 273285, 2013.

LE ROUX, M. Le Wagon Brasil lança a opção ISA (Income Share Agreement). Blog Le Wagon, 23 abr. 2020. Disponível em: <https://bit.ly/36AstEC>. Acesso em: 28 maio 2020.

LERGETPORER, P.; WOESSMANN, L. The political economy of university tuition fees: information provision and income contingency in representative survey experiments. Munique: IFO Institute at the University of Munich, 2019.

LINHARES DE MELO, A. Possíveis contribuiçôes das escriturações tributárias digitais para automatização da cobrança do Fies. In: CONFERÊNCIA INTERNACIONAL SOBRE FINANCIAMENTO VINCULADO À RENDA: ALTERNATIVAS PARA O ENSINO SUPERIOR E OUTRAS ÁREAS DE POLÍTICA PÚBLICA. Anais... Brasília, 10-12 jul. 2019. Disponível em: <https://bit.ly/2lGl8A4>. Acesso em: 6 set. 2019.

MEDEIROS, M.; PINHEIRO, L. S. Desigualdades de gênero em tempo de trabalho pago e não pago no Brasil, 2013. Sociedade e Estado, v. 33, n. 1, p. 159-185, abr. 2018.

MEDEIROS, M.; SOUZA, P. H.; CASTRO, F. A. O topo da distribuição de renda no Brasil: Primeiras estimativas com dados tributários e comparação com pesquisas domiciliares (20062012). Dados, v. 58, n. 1, p. 7-36, 2015.

NASCIMENTO, P. M. Compartilhamento de custos e crédito estudantil contingente à renda: possibilidades e limitaçóes de aplicaçóes para o Brasil. Brasília: Ipea, ago. 2016. (Texto para Discussão, n. 2.220). Disponível em: <https://bit.ly/2DNBTBT>. Acesso em: 4 abr. 2018. 
Modelling income contingent loans for higher education student financing in

Brazil. Tese (Doutorado) - Universidade Federal da Bahia, Salvador, 2018. Disponível em: <https://bit.ly/2MyWUER>. Acesso em: 29 jan. 2019.

OCDE - ORGANIZAÇÃO PARA A COOPERAÇÃO E DESENVOLVIMENTO ECONÔMICO. Education at a glance 2020: OECD indicators. Paris: OECD Publishing, 2020.

PALACIOS, M. Investing in human capital: a capital markets approach to student funding. London: Cambridge University Press, 2007.

. The relationship between income share agreements and income contingent loans, and why we need both. In: CONFERENCIA INTERNACIONAL SOBRE FINANCIAMENTO VINCULADO À RENDA: ALTERNATIVAS PARA O ENSINO SUPERIOR E OUTRAS ÁREAS DE POLÍTICA PÚBLICA. Anais... Brasília, 10-12 jul. 2019. Disponível em: <https://bit.ly/2ln0PYk>. Acesso em: 6 set. 2019.

SHEN, H.; ZIDERMAN, A. Student loans repayment and recovery: international comparisons. Higher education, v. 57, n. 3, p. 315-333, 2009.

STARTUP que forma desenvolvedor e cobra após aluno conseguir emprego capta R $\$ 42$ milhóes. Isto é Dinheiro, 28 fev. 2020. Disponível em: <https://bit.ly/3epvfzd>. Acesso em: 28 maio 2020 .

STIGLITZ, J. E. Income contingent loans: some general theoretical considerations, with applications. In: STIGLITZ, J. E.; GUZMAN, M. (Eds.). Contemporary issues in Microeconomics. London: Palgrave Macmillan, 2016. 


\section{APÊNDICE A}

\section{Detalhamento de como foram feitas as simulações dinâmicas}

$\mathrm{Na}$ seção 3, quando apresentada sumariamente a metodologia descrita em Dearden (2019b) para as simulações feitas neste trabalho, foi dito que a função de cópula bivariada que melhor captou a distribuição conjunta do painel com dados das Pesquisas Nacionais por Amostra de Domicílio Contínuas (PNADs Contínuas) de 2014 e 2015 foi a student's t copula ( $t$-cópula). O Critério de Informação de Akaike (AIC, na sigla em inglês) foi usado para escolher a t-cópula entre todas as várias famílias de cópulas bivariadas disponíveis na função BiCopSelect do pacote "VineCopula" do software estatístico R. ${ }^{1}$

As famílias de cópulas bivariadas disponíveis na função BiCopSelect do pacote "VineCopula" foram testadas para todas as quarenta transiçóes de idade que existem entre os 24 e os 64 anos. O AIC apontou a t-cópula para 22 transiçôes de idade para as mulheres e 29 transições de idade para os homens. A t-cópula mostrou-se particularmente apropriada para a maioria das transiçóes de idade entre as idades de 24 a 50 anos entre as mulheres e 24 a 55 anos entre os homens. Para idades mais avançadas já não teve um desempenho tão bom, possivelmente refletindo números menores de amostras e mudanças mais pronunciadas na evolução dos rendimentos à medida que as pessoas envelhecem.

Estabelecida a cópula apropriada para formalizar as estruturas de dependência da distribuição de rendimentos dos graduados no Brasil, o pacote "Copula" ${ }^{2}$ do software $\mathrm{R}$ foi utilizado para estimar os parâmetros relevantes para as t-cópulas: a correlaçáo rho $(\rho)$ e os graus de liberdade $(v)$. São esses dois parâmetros que permitem projetar para os anos a serem simulados o padrão de mobilidade de renda encontrado no painel real de pessoas com nível superior usado neste trabalho. Ambos podem ser estimados por máxima verossimilhança (MLE, na sigla em inglês), mas o processo de maximização subjacente a esse método tende a ser muito lento em momentos mais altos. Assim, mesmo

1. Sobre funções de cópula, ver Scaillet, Charpentier e Fermanian (2007) e Nelsen (2006). Especificamente sobre t-cópulas, ver Demarta e McNeil (2005). Sobre o AIC, ver Sakamoto, Ishiguro e Kitagawa (1986). A escolha da função de cópula mais apropriada foi feita por AIC usando a versão v2.1.6 do pacote "VineCopula", documentada para o R por Nagler ([s.d.]), disponivel em: <https://bit.ly/39IRGzC>.

2. Foi usada a versão v0.999-18 do pacote "Copula", documentada para o R por Maechler, disponível em: <https://bit. ly/3cMSnu3>. 
para as t-cópulas bidimensionais, é prática comum estimar $\rho$ por método-de-momentos usando tau de Kendall, e entáo estimar o parâmetro $v$ por MLE (Demarta e McNeil, 2005; McNeil, Frey e Embrechts, 2015).

Dearden (2019b) interpreta o parâmetro $\rho$ como descrevendo o nível geral de imobilidade na distribuição. Quanto maior seu valor, menor a mobilidade na distribuição de rendimentos dos graduados. O outro parâmetro, $v$, pode ser interpretado como o excesso de imobilidade nas caudas da distribuição. Quanto menor seu valor, menor a mobilidade tanto na base, quanto no topo da distribuiçáo de rendimentos das pessoas com nível superior. O gráfico A.1 mostra as estimativas, por idade, do parâmetro $\rho$ e do parâmetro $v$, como também seus intervalos de confiança e suas estimativas suavizadas (que são as efetivamente utilizadas nas simulaçóes), separadamente para homens e para mulheres com curso superior.

O gráfico A.1 mostra um nível crescente de imobilidade na distribuiçáo de rendimentos para graduados no Brasil por aproximadamente dez anos após a formatura. Em seguida, a distribuição de rendimentos torna-se um pouco mais móvel para os homens até atingirem os 50 anos, mas o nível de imobilidade para as mulheres continua a aumentar. Após essa idade, a imobilidade para os homens retorna aproximadamente ao mesmo nível observado para quando tinham 30 anos, mas cai drasticamente para as mulheres. O gráfico A.1 também mostra que os indivíduos na parte inferior (ou superior) da distribuição de rendimentos enfrentam maiores chances de mobilidade ascendente (ou descendente) nos primeiros anos após a formatura e novamente quando próximos à idade-limite de pagamento em nossas simulaçóes. No entanto, os grandes intervalos de confiança nas idades mais avançadas, especialmente onde os tamanhos das amostras de pós-graduação são muito menores (particularmente para as mulheres), significam que é necessário cautela na interpretação dos padrôes de mobilidade para as pessoas com mais de 50 anos. 
GRÁFICO A.1

Estimativas dos parâmetros relevantes para a t-cópula da distribuição conjunta dos dois anos de observações para o painel de pessoas com nível superior usado nas simulações
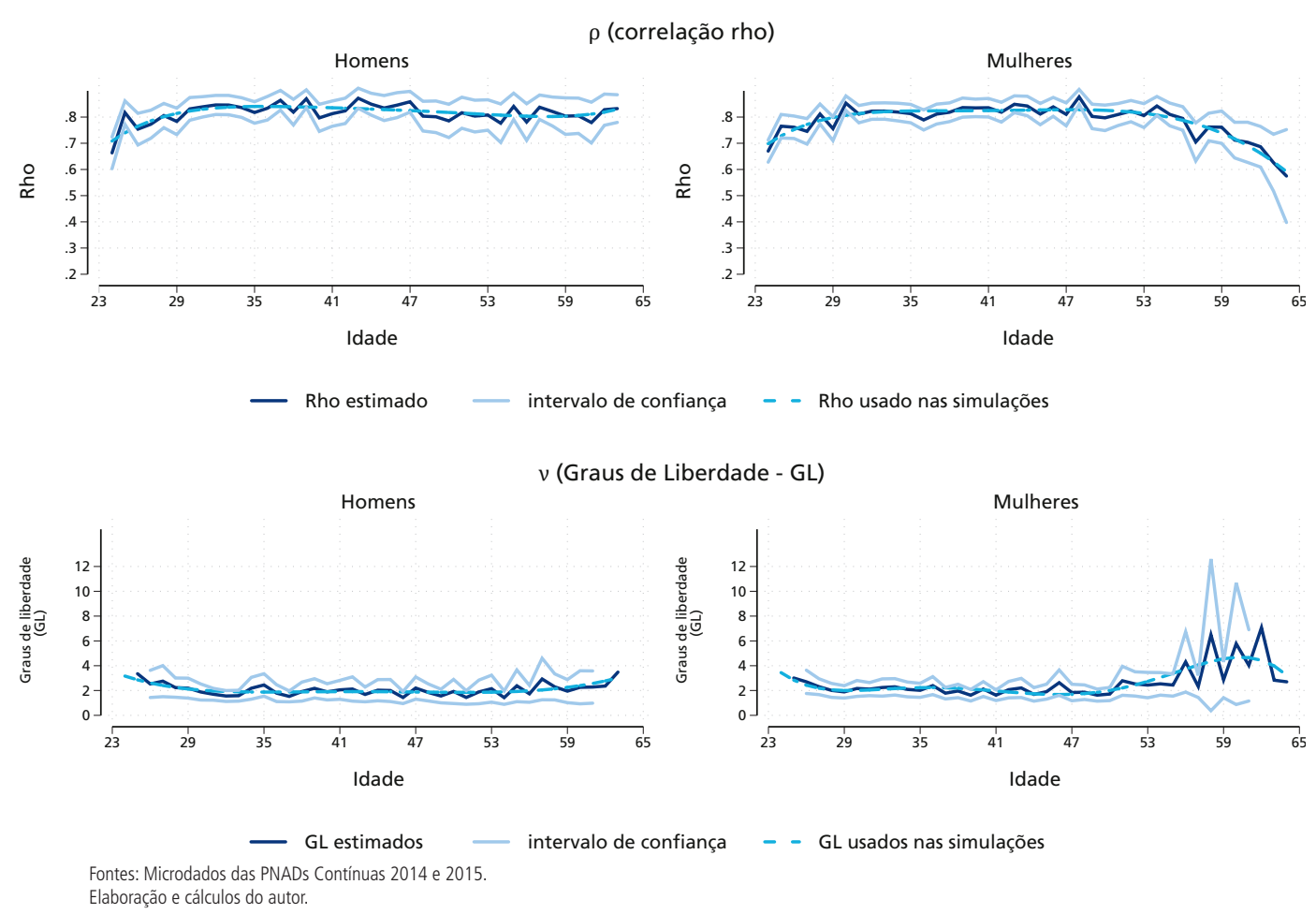

Obtidas as estimativas do parâmetro $\rho$ e do parâmetro $v$, as simulaçôes dinâmicas são feitas da forma a seguir.

1) Recorre-se ao painel original de 25.240 pessoas $^{3}$ para sortear, com substituição, 10 mil mulheres e 10 mil homens de 24 anos.

2) Estima-se a distribuição condicional da função de distribuição acumulada (FDA) marginal aos 25 anos $\left(u_{25}\right)$, dada a FDA marginal aos 24 anos $\left(u_{24}\right)$, que é representada por: $c_{u_{24}}\left(u_{25}\right) \stackrel{\partial}{\partial u_{24}} C_{24}\left(u_{24}, u_{25}\right)$, em que $C_{24}$ é a t-cópula estimada com os parâmetros $v$ e $\rho$ de as estimativas suavizadas (smoothed estimates) obtidas para a idade de 24 anos.

3. Ver estatísticas descritivas na tabela 2. 
3) Gera-se uma variável aleatória $r$ com distribuição uniforme padrão e com a mesma dimensão de $u_{24}(10 \mathrm{mil})$.

4) Gera-se $u_{25}=c_{u_{24}}^{-1}(r)$ para obter a posição predita e uniformemente distribuída aos 25 anos. O elemento estocástico deve-se à predição de classificação ser determinada pelo sorteio uniformemente aleatório.

5) Repetem-se os passos 2 a 5 para cada idade adjacente, até que se chegue aos 64 anos de idade. Só então essas simulações são reponderadas por sexo, a fim de refletir as taxas de conclusão específicas para cada gênero no Brasil em 2017, ano da mais recente edição anual do Censo do Ensino Superior disponível quando este trabalho foi concluído.

As simulações obtidas refletem bem as dependências esperadas nos rendimentos dos brasileiros com nível superior a cada vez que mudam de idade? Além de examinar as dependências gerais e as dependências nas caudas da distribuição de rendimentos (que é o que revelam, respectivamente, a evolução das estimativas do parâmetro $\rho$ e a evolução das estimativas do parâmetro $v$ ), também cabe analisar sua dependência monótona, também chamada, no campo da estatística, de concordância.

Pares de FDAs $\left\{\left(u_{t i}, u_{t+1 i}\right),\left(u_{t j}, u_{t+1 j}\right)\right\}$ são concordantes se ambos os valores do primeiro par forem maiores do que os valores correspondentes do outro par. Isto é, são concordantes se $u_{t i}<u_{t j}$ e $u_{t+1 i}<u_{t+1 j}$ ou $u_{t i}>u_{t j}$ e $u_{t+1 i}>u_{t+1 j}$. Eles são discordantes se para um par um valor é maior e o outro valor é menor do que seus correspondentes no outro par. Isto é, são discordantes se $u_{t i}<u_{t j}$ e $u_{t+1 i}>u_{t+1 j}$ ou $u_{t i}>u_{t j}$ e $u_{t+1 i}<u_{t+1 j}$ (Nelsen, 2002).

No estudo das relaçóes entre a concordância de variáveis aleatórias e suas cópulas, três medidas comuns de associação são Tau de Kendall, Rho de Spearman e o coeficiente de Gini (Nelsen, 2002). Seguindo Dearden (2019b), a medida de associação que usamos é Tau de Kendall $(\tau) .{ }^{4} \mathrm{O}$ gráfico A. 2 compara, para todas as transições de idade, a dependência monótona dos dados reais do painel com as previsôes do modelo com t-cópula e com as estimativas suavizadas usadas nas simulaçóes.

4. Ver Dearden (2019) para detalhes sobre a estimativa de $\tau$. 
GRÁFICO A.2

Medindo o grau de concordância das FDAs dos rendimentos em idades adjacentes usando a tau de Kendall: estimativas do painel inicial, da t-cópula e das simulações com pseudo-observações

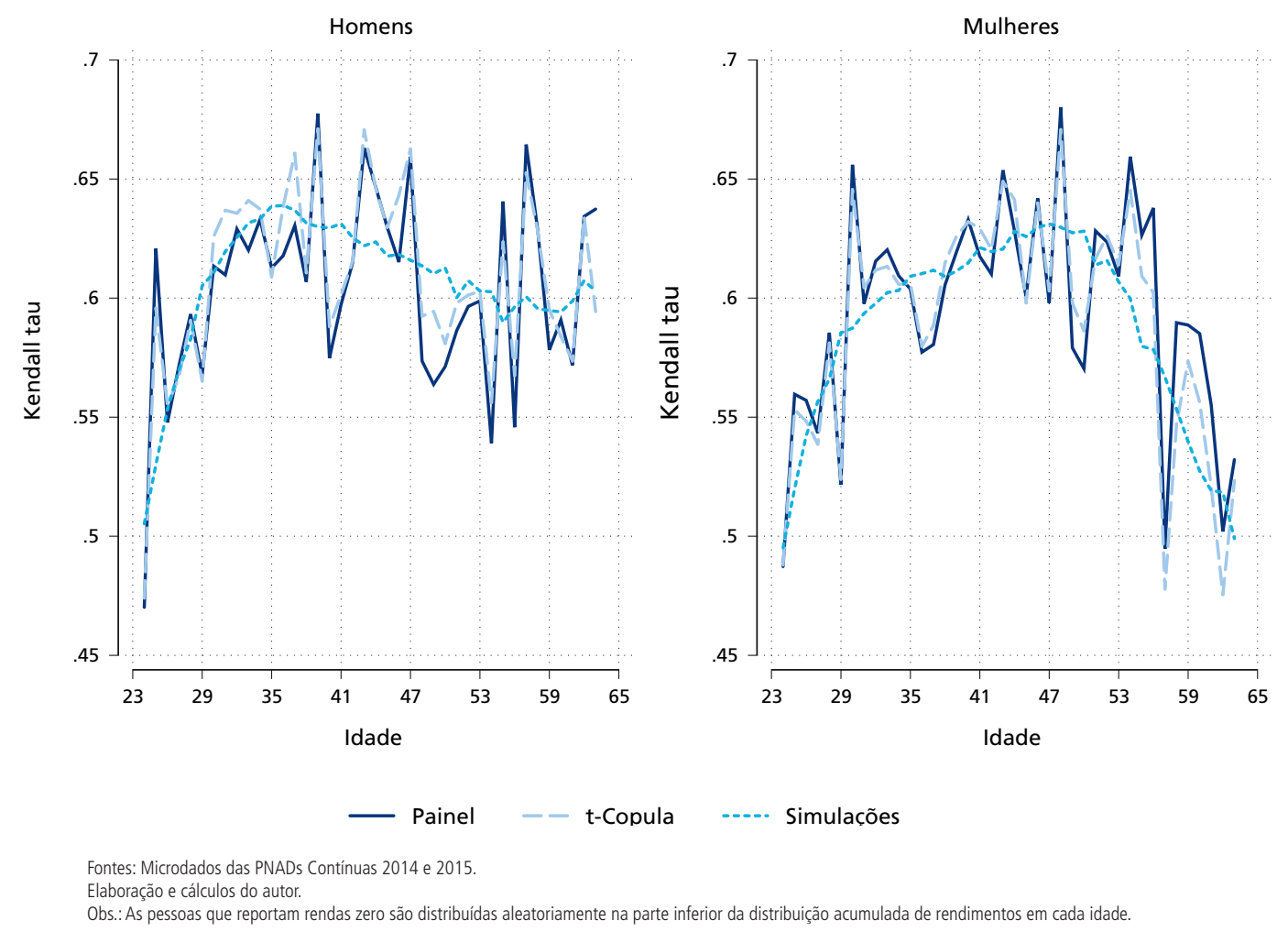

O gráfico A.2 mostra que as estimativas tanto da t-cópula quanto da amostra simulada replicam satisfatoriamente as estruturas de dependência sobre idades adjacentes dos dados em painel obtidos da PNAD Contínua. Interpretados em conjunto, o gráficos A.1 e A.2 sugerem que a distribuição dos rendimentos dos brasileiros de nível superior é caracterizada por baixa mobilidade e alta dependência em idades adjacentes, particularmente em comparação com os americanos com nível superior analisados em Dearden (2019b).

Vale a pena destacar que as tendências de mobilidade e dependência tendem a variar quando coortes diferentes são tomadas para análise. Além disso, os modelos de cópula usados neste trabalho só consideram a dependência de primeira ordem. É provável que o ponto da distribuiçáo de rendimentos onde uma pessoa se encontra em um momento de sua vida seja parcialmente determinado por resultados de anos 
anteriores, não apenas do ano que imediatamente precede ao do momento em questão. Não é possível testar isso no Brasil porque só conseguimos observar transições de renda de um ano para outro.

Malgrado suas limitaçôes, os perfis dinâmicos de idade-renda obtidos neste trabalho são uma aproximação das futuras trajetórias de rendimentos para quem tem nível superior no Brasil. Junto com os perfis de idade-renda obtidos pelas simulaçôes estáticas formam um intervalo para o padrão esperado de renda futura dos egressos do sistema de ensino superior brasileiro. Não permitem estimar padróes de amortizaçáo de um Empréstimo com amortizaçôes condicionadas à renda (ECR) para egressos de tipos específicos de instituiçóes ou de áreas de conhecimento, pois a PNAD Contínua não dá esse detalhamento para quem já concluiu curso superior. ${ }^{5}$ Permitem, contudo, simular cenários de pagamento de um ECR que tivesse alcance virtualmente universal para a população brasileira com ensino superior.

\section{REFERÊNCIAS}

DEARDEN, L. Designing sustainable income contingent loans. In: CONFERÊNCIA INTERNACIONAL SOBRE FINANCIAMENTO VINCULADO À RENDA: ALTERNATIVAS PARA O ENSINO SUPERIOR E OUTRAS ÁREAS DE POLÍTICA PÚBLICA. Anais... Brasília, 10-12 jul. 2019a. Disponível em: <https://bit.ly/2lelOwH>. Acesso em: 6 set. 2019.

Evaluating and designing student loan systems: an overview of empirical approaches. Economics of education review, v. 71, p. 49-64, Aug. 2019b.

DEMARTA, S.; MCNEIL, A. J. The t copula and related copulas. International statistical review, v. 73, n. 1, p. 111-129, 2005.

MCNEIL, A. J.; FREY, R.; EMBRECHTS, P. Quantitative risk management: concepts, Techniques and Tools-revised edition. Princeton University Press, 2015.

NELSEN, R. B. Concordance and copulas: a survey. In: CUADRAS, C. M.; FORTIANA, J.; RODRIGUEZ-LALLENA, J. A. (Eds.). Distributions with given marginals and statistical modelling. Dordrecht: Springer, 2002. p. 169-177.

An introduction to copulas. 2. ed. New York: Springer-Verlag, 2006.

5. Como discutido na seção 3, microdados de outras fontes seriam necessários para essa finalidade. 
SAKAMOTO, Y.; ISHIGURO, M.; KITAGAWA, G. Akaike Information Criterion statistics. Heidelberg, Alemanha: Springer Netherlands, 1986.

SCAILLET, O.; CHARPENTIER, A.; FERMANIAN, J.-D. The estimation of copulas: Theory and practice. In: RANK, J. (Ed.). Copulas: from theory to application in finance. Londres: Risk Books, 2007. p. 35-64. 


\section{APÊNDICE B}

\section{Resumo de como foram feitas as simulações estáticas}

$\mathrm{Na}$ ausência de dados longitudinais, uma vertente da literatura de empréstimos estudantis estima os perfis de idade-renda usando dados transversais para simular o pagamento de empréstimos estudantis em diferentes partes da distribuição de renda dos graduados. A maioria dos estudos que aplicam essa abordagem baseia-se em dados de pesquisas amostrais ou de registros administrativos. A rigor, bastaria calcular o nível de comprometimento da renda e simular padrôes de amortização diretamente dos dados brutos tabulados por idade em diferentes quantis, desde que observada a ponderação apropriada para os dados utilizados. No entanto, como geralmente há alta volatilidade nos rendimentos, alguma suavização é desejável.

Existem várias maneiras de suavizar dados de fluxos de renda. Não há sequer a necessidade de se recorrer a regressóes para essa finalidade, mas essa é a tradição nesse ramo da literatura. Os perfis de idade-renda costumam ser suavizados partindo-se de equaçôes mincerianas de salários que têm como regressores apenas polinômios da variável idade ou da variável experiência potencial, sendo esta última dada pela diferença entre a idade do indivíduo no ano de análise e a idade em que se assume que todas as pessoas da amostra concluíram seu curso superior - nada mais do que uma transformação monotônica da variável idade.

Escolaridade não aparece como regressor, pois apenas os rendimentos de pessoas com nível superior são modelados - e os eventuais prêmios salariais decorrentes de estudos em nível de pós-graduação não são considerados, por simplicidade. Pela mesma razão, assume-se que nenhuma renda é obtida antes de concluir o curso. É comum os dados serem analisados em separado por sexo, podendo também a amostra ser separada por raça, regiáo ou qualquer outro recorte que interesse aos pesquisadores e para o qual seja possível gerar subamostras grandes o suficiente com os dados disponíveis. Viés de seleção não é um problema para o que se busca aqui. Pelo contrário, seus reflexos nos perfis de idade-renda são importantes para a análise, uma vez que a capacidade de pagamento em diferentes momentos da vida é o que interessa para fins de simulação de um programa de financiamento. 
A inovação desse método está em estimar, com dados de um único ano, o percentual da renda que ficaria comprometida para cada pessoa da amostra, ano a ano, com o pagamento de uma dívida estudantil. O método foi desenvolvido por Lounkaew (2012) e replicado, entre outras obras, em Chapman e Liu (2013), Chapman e Suryadarma (2013), Chapman e Sinning (2014) e Chapman e Lounkaew (2015) para estimar, em variados países, o quanto da renda de seus graduados ficaria comprometida durante a fase de amortização de um programa convencional de crédito educacional. Também tem sido usado para ilustrar perfis de pagamento em sistemas alternativos de empréstimo, incluindo empréstimos com amortizaçôes condicionadas à renda (ECRs). ${ }^{1}$ Três são as vantagens desse método: i) é fácil de implementar; ii) é replicável com qualquer banco nacional de dados transversais com informaçôes disponíveis sobre a idade dos graduados e seus rendimentos; e iii) seus resultados são ilustrativos para formuladores de políticas.

A limitação maior dessa abordagem está em não levar em conta o fato de que a maioria das pessoas transita ao longo de suas vidas entre situaçôes de emprego, de desemprego, de desalento e de saídas momentâneas e opcionais da força de trabalho. Também varia a qualidade da inserção no mundo do trabalho a cada etapa da vida. Tudo isso se reflete no padrão de renda das pessoas. Ignorar a dinâmica do mundo de trabalho e os padróes de mobilidade de renda leva a perfis de pagamento irrealistas (Dearden, 2019; Higgins e Sinning, 2013). Na prática, o método tende a superestimar o número de anos de comprometimento excessivo da renda para pagar débitos estudantis e o tempo necessário para zerar a dívida, além de subestimar a capacidade de pagamento das pessoas na hipótese de vincular os pagamentos de suas dívidas estudantis aos seus fluxos de renda ao longo da vida. Serve, contudo, como uma estimativa máxima das perdas fiscais de um ECR por incapacidade de pagamento, como também do número máximo de anos que cada tipo de egresso levaria para pagá-lo por completo.

A maioria dos estudos nesse ramo da literatura faz suas simulaçóes estáticas aplicando regressóes quantílicas incondicionais e colocando apenas idade e idade ao quadrado no lado direito da equação. Segue-se neste trabalho a variante proposta por Dearden (2019b), que mostra ser mais apropriado o uso de regressóes quantílicas condicionais e de polinômio de quinto grau para a variável idade (ou para sua transformação monotônica em experiência potencial). Mais detalhes podem ser encontrados em Nascimento (2018).

1. Ver, por exemplo, Cai, Chapman e Wang (2019), Chapman e Doris (2019), para simulações de ECRs respectivamente para a China e a Irlanda. 


\section{REFERÊNCIAS}

CAI, Y.; CHAPMAN, B.; WANG, Q. Repayment burdens of mortgage-style student loans in China and steps toward income-contingent loans. Economics of education review, v. 71, p. 95-108, Aug. 2019.

CHAPMAN, B.; DORIS, A. Modelling higher education financing reform for Ireland. Economics of education review, v. 71, p. 109-119, Aug. 2019.

CHAPMAN, B.; LIU, A. Y. C. Repayment burdens of student loans for Vietnamese higher education. Economics of education review, v. 37, p. 298-308, Dec. 2013.

CHAPMAN, B.; LOUNKAEW, K. An analysis of Stafford loan repayment burdens. Economics of education review, v. 45, p. 89-102, Apr. 2015.

CHAPMAN, B.; SINNING, M. Student loan reforms for German higher education: financing tuition fees. Education Economics, v. 22, n. 6, p. 569-588, 2014.

CHAPMAN, B.; SURYADARMA, D. Financing higher education: the viability of commercial student loan scheme in Indonesia. In: SURYADARMA, D.; JONES, G. W. (Eds.). Education in Indonesia. Cingapura: Iseas, 2013. p. 203-215.

DEARDEN, L. Designing sustainable income contingent loans. In: CONFERÊNCIA INTERNACIONAL SOBRE FINANCIAMENTO VINCULADO À RENDA: ALTERNATIVAS PARA O ENSINO SUPERIOR E OUTRAS ÁREAS DE POLÍTICA PÚBLICA. Anais... Brasília, 10-12 jul. 2019a. Disponível em: <https://bit.ly/2lelOwH>. Acesso em: 6 set. 2019.

Evaluating and designing student loan systems: an overview of empirical approaches.

Economics of education review, v. 71, p. 49-64, Aug. 2019 b.

HIGGINS, T.; SINNING, M. Modelling income dynamics for public policy design: an application to income contingent student loans. Economics of education review, v. 37, p. 273 $285,2013$.

LOUNKAEW, K. Essays on economic analysis of student Loans. Tese (Doutorado) - Australian National University, Canberra, 2012.

NASCIMENTO, P. M. Modelling income contingent loans for higher education student financing in Brazil. Tese (Doutorado) - Universidade Federal da Bahia, Salvador, 2018. Disponível em: <https://bit.ly/2MyWUER>. Acesso em: 29 jan. 2019. 


\section{APÊNDICE C}

\section{Resultados de simulações adicionais}

Apresentam-se, neste apêndice, os resultados de algumas simulaçôes adicionais às que foram apresentadas na seção 4 .

A primeira simulação adicional segue exatamente os mesmos parâmetros do cenário preferencial cujos resultados foram exibidos no gráfico 1 . A única diferença é que, neste caso, as alíquotas do empréstimo com amortizaçóes condicionadas à renda (ECR) incidem sobre o rendimento bruto total, ao invés de incidirem sobre a renda marginal. Como enfatizado na seção 4 , isto faz com que caiam os tempos médios de amortização e aumentem as taxas de recuperação de crédito. Esse cenário está ilustrado no gráfico C.1.

Em comparação com o desenho em que as alíquotas propostas incidiam sobre a renda marginal, o novo desenho reduz o tempo médio de amortização entre cinco e sete anos. Homens levariam, em média, entre catorze e cinquenta anos pagando o ECR, sendo que entre os $10 \%$ mais ricos esse tempo cairia para algo entre cinco e onze anos. Com as alíquotas incidindo sobre a renda marginal, ${ }^{1}$ os homens levariam, em média, entre vinte e 26 anos pagando suas dívidas estudantis, e até mesmo os $10 \%$ mais ricos poderiam levar até catorze anos pagando. Mulheres levariam, em média, 22 a 28 anos com dívida estudantil se as alíquotas propostas incidissem sobre a renda bruta total (sobre a renda marginal, levariam de trinta a 33 anos), sendo que as $10 \%$ mais ricas precisariam de seis a catorze anos para zerar a dívida (com alíquotas sobre a renda marginal levariam entre nove e dezenove anos).

Alíquotas sobre a renda bruta total permitiriam recuperar consideravelmente mais crédito. Homens pagariam entre $82 \%$ e $98 \%$ do valor presente líquido (VPL) do ECR, enquanto mulheres pagariam entre $60 \%$ e $90 \%$, com alíquotas sobre o rendimento bruto total. Na média, seriam recuperados entre $68 \%$ (de acordo com a simulação estática) e $93 \%$ (de acordo com a simulaçáo dinâmica). Vale lembrar que, com as mesmas alíquotas incidindo sobre a renda marginal, recuperava-se entre $55 \%$ e $85 \%$ do crédito concedido.

1. Ver gráfico 1 na seção 4.

60 
GRÁFICO C.1

Número de anos até zerar dívida e percentual pago do VPL da dívida no cenário de ECR preferencial, com alíquotas incidentes sobre renda bruta total, homens e mulheres, por decil de renda e totais, simulação estática e simulação dinâmica - Brasil

Por quanto tempo pagam?

C.1A - Homens

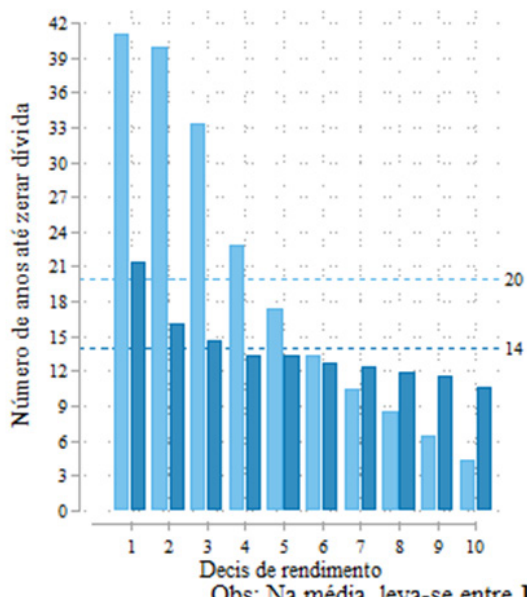

C.1B - Mulheres

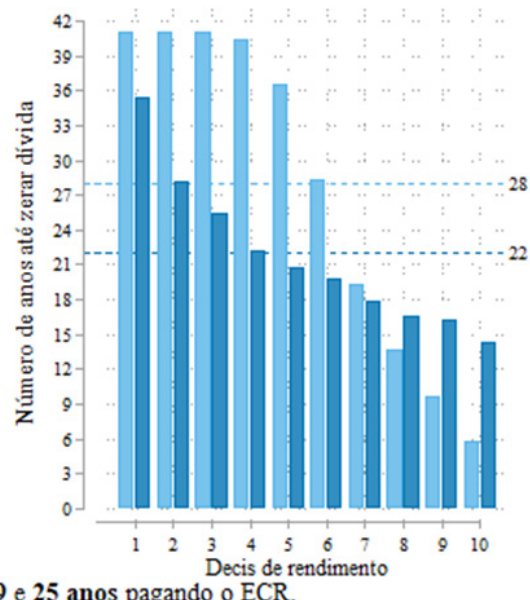

Que percentual do empréstimo pagam?

C.1C - Homens

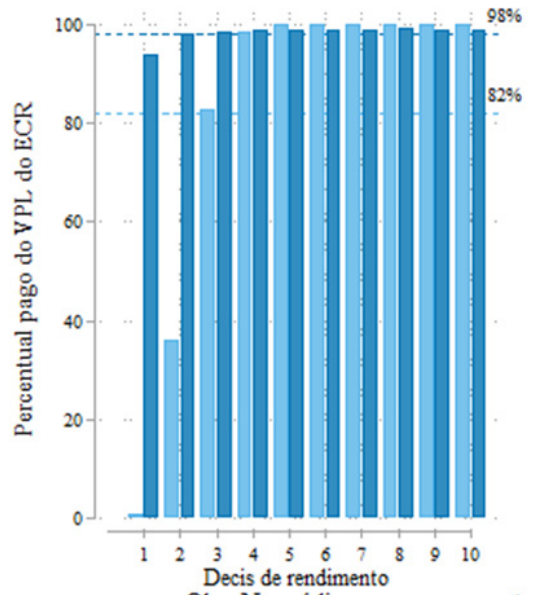

C.1D - Mulheres

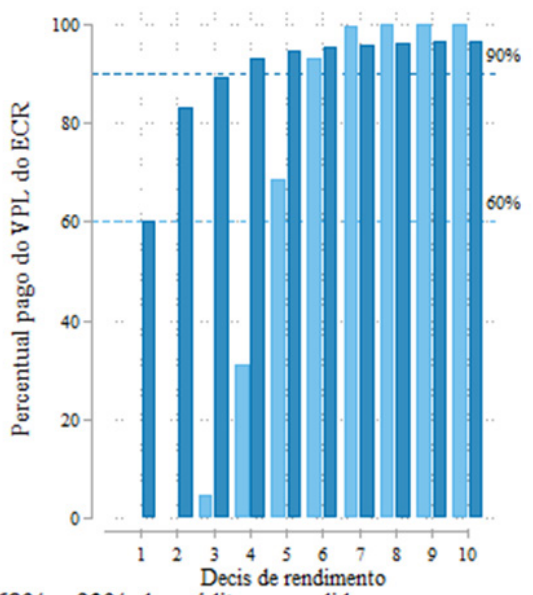

Obs: Na média, recupera-se entre $68 \%$ e $93 \%$ do crédito concedido.

Estática: sem mobilidade de renda

Dinâmica: com mobilidade de renda 
Como argumentado na seção 4, alíquotas sobre a renda marginal, além das vantagens apontadas pela literatura, seriam de mais fácil implementação pela Receita Federal do Brasil (RFB) - que já adota alíquotas desse tipo para fins de Imposto de Renda Pessoa Física (IRPF) e de mais fácil compreensão em um desenho como o proposto neste trabalho - pois significariam, na prática, uma sobretaxa no IRPF. Se aplicadas sobre a renda bruta total, contudo, as mesmas alíquotas melhoram bastante o desempenho fiscal. Como estáo abaixo do limite tido pela literatura como manejável para os devedores, não seria um problema grande adotá-las sobre a renda total. Uma alternativa poderia ser, de todo modo, aumentar as alíquotas do ECR e mantê-las incidindo sobre a renda marginal. 
GRÁFICO C.2

Número de anos até zerar dívida e percentual pago do VPL da dívida no cenário de ECR mais pessimista, com alíquotas incidentes sobre renda bruta marginal, renda real estagnada, juro real zero e custo real de financiamento do governo igual a 7,6\% ao ano, homens e mulheres, por decil de renda e totais, simulação estática e simulação dinâmica - Brasil

Por quanto tempo pagam?

C.2A - Homens

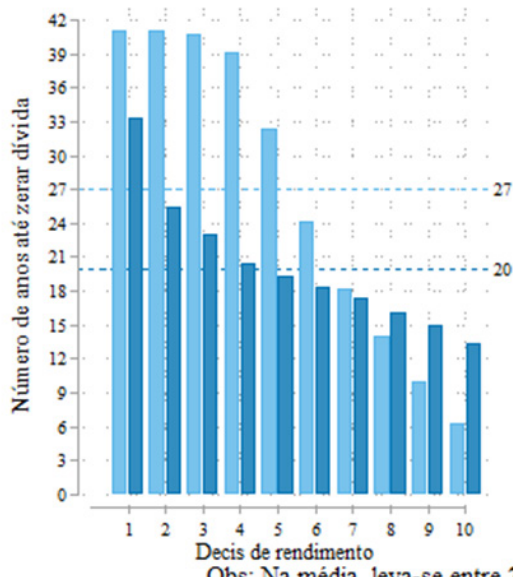

C.2B - Mulheres

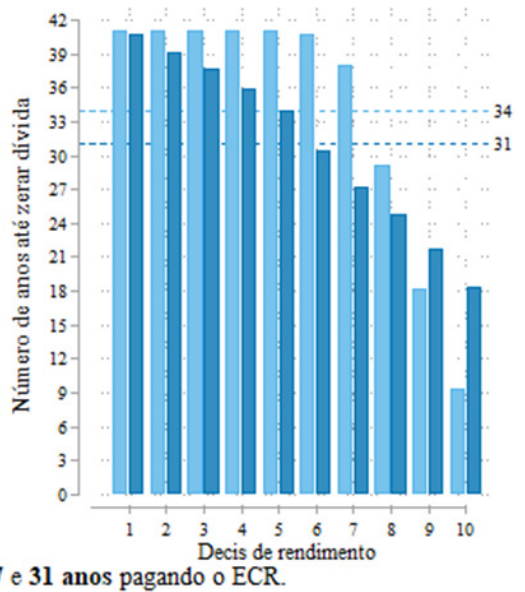

Que percentual do empréstimo pagam?

C. $2 \mathrm{C}$ - Homens

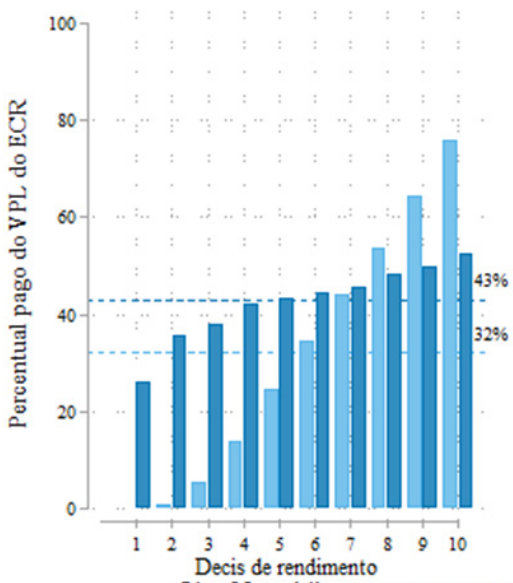

Obs: Na média, recupera-se entre $23 \%$ e $33 \%$ do crédito concedido.
C.2D - Mulheres

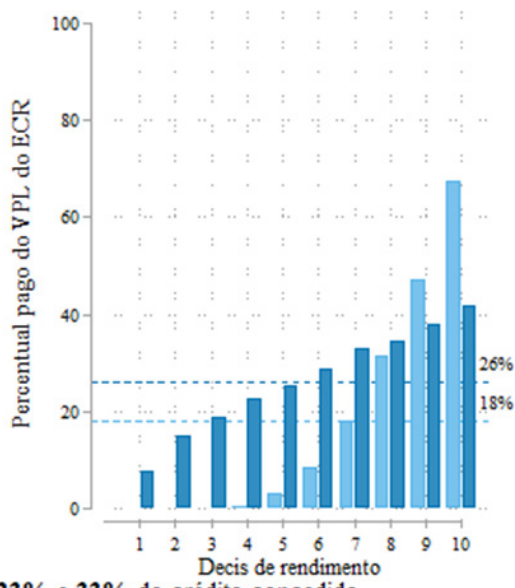

Dinâmica: com mobilidade de renda

Elaboração do autor. 
Dezenas de outras simulaçóes adicionais foram feitas. Nelas são modificados os pressupostos assumidos em relação à taxa de desconto e à evolução real dos rendimentos das pessoas de nível superior. Optou-se por reportar aqui, para o desenho preferencial de ECR, apenas os resultados do cenário mais pessimista, que tenderia a impor maior custo fiscal (gráfico C.2), e os resultados do cenário mais otimista, que tenderia a apresentar o menor custo fiscal para o ECR (gráfico C.3). São cenários que ilustram extremos. 
GRÁFICO C.3

Número de anos até zerar dívida e percentual pago do VPL da dívida no cenário de ECR mais otimista, com alíquotas incidentes sobre renda bruta total, renda real crescendo $2 \%$ ao ano, juro real e custo real de financiamento do governo igual a $2 \%$ ao ano, homens e mulheres, por decil de renda e totais, simulação estática e simulação dinâmica - Brasil Por quanto tempo pagam?

C.3A - Homens

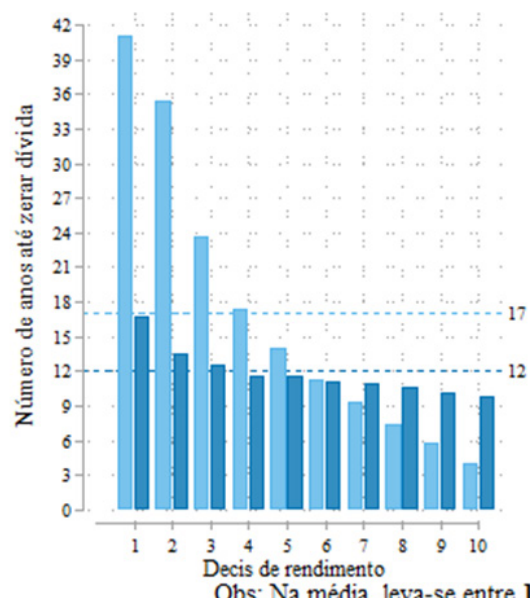

C.3B - Mulheres

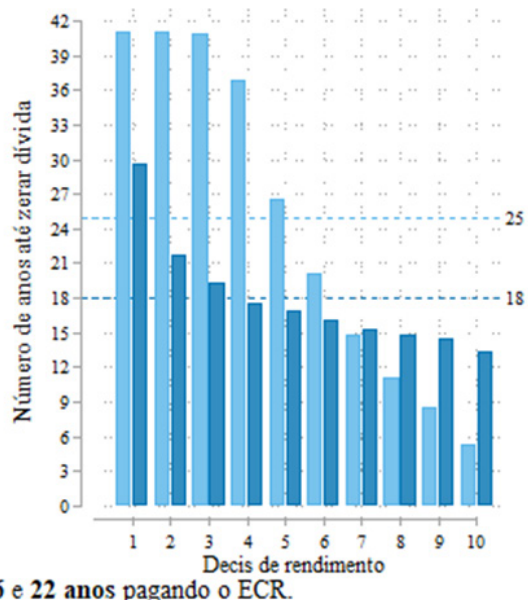

Que percentual do empréstimo pagam?

C.3C - Homens

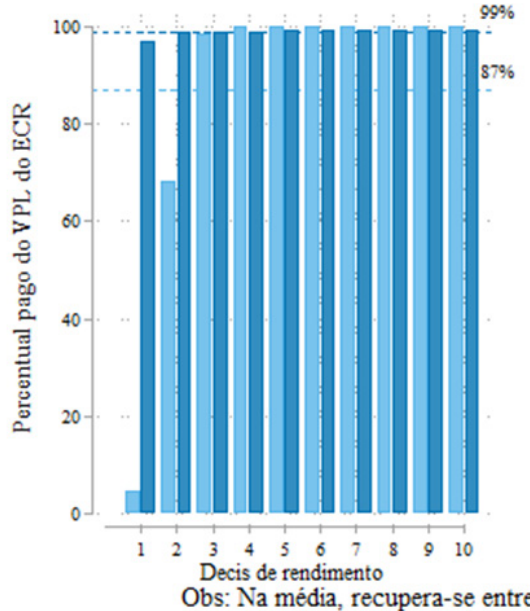

Obs: Na média, recupera-se entre $75 \%$ e $96 \%$ do crédito concedido.
C.3D - Mulheres

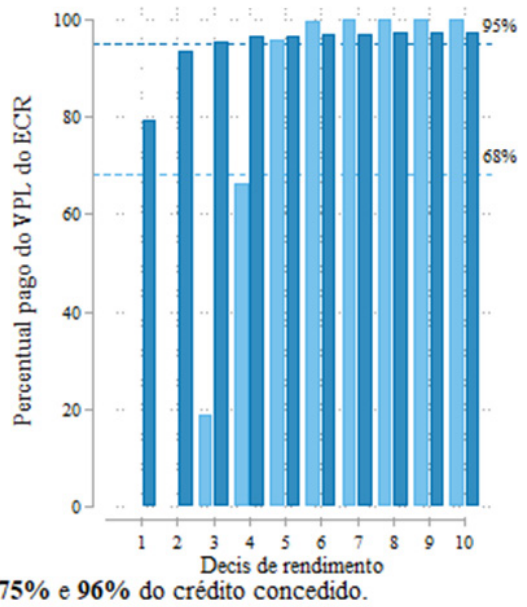

Dinâmica: com mobilidade de renda

Elaboração do autor. 
O cenário mais pessimista (gráfico C.2) remete aos parâmetros da tabela 3, exceto que o ECR é corrigido só pela inflação. Suas alíquotas incidem sobre a renda marginal, mas em um cenário em que o custo de financiamento do governo é de 7,6\% ao ano (a.a.) e a renda dos graduados permanece estagnada durante toda a fase de amortização. O cenário otimista (gráfico C.3) segue exatamente os mesmos parâmetros da tabela 3, mas com alíquotas incidentes sobre a renda bruta total em um cenário em que o custo de financiamento do governo é menor (2\% a.a.) e a renda das pessoas com nível superior cresce a uma taxa real de $2 \%$ a.a. todos os anos da simulação.

O cenário mais pessimista mostra que mesmo um desenho com juro real zero tenderia a apresentar resultados fiscais muito ruins sob condições muito adversas (renda estagnada e taxa básica de juros muito alta). Já o desenho preferencial melhoraria ainda mais o desempenho fiscal do ECR sob o cenário mais otimista. Vê-se, pois, que tanto fatores endógenos (relativos ao desenho) quanto fatores exógenos (relativos às condiçôes macroeconômicas) importam para o sucesso do ECR. Cabe ao gestor da política garantir que o desenho do ECR seja suficientemente bem-feito para maximizar ganhos em cenários favoráveis e minimizar perdas em cenários adversos, sempre protegendo, além do contribuinte, também o estudante. 

Ipea - Instituto de Pesquisa Econômica Aplicada

\title{
EDITORIAL
}

Chefe do Editorial

Reginaldo da Silva Domingos

Assistentes da Chefia

Rafael Augusto Ferreira Cardoso

Samuel Elias de Souza

\section{Supervisão}

Camilla de Miranda Mariath Gomes

Everson da Silva Moura

\section{Editoração}

Aeromilson Trajano de Mesquita

Anderson Silva Reis

Cristiano Ferreira de Araújo

Danielle de Oliveira Ayres

Danilo Leite de Macedo Tavares

Jeovah Herculano Szervinsk Junior

Leonardo Hideki Higa

\section{Capa}

Danielle de Oliveira Ayres

Flaviane Dias de Sant'ana

\section{Projeto Gráfico}

Renato Rodrigues Bueno

The manuscripts in languages other than Portuguese published herein have not been proofread.

\author{
Livraria Ipea \\ SBS - Quadra 1 - Bloco J - Ed. BNDES, Térreo \\ 70076-900 - Brasília - DF \\ Tel.: (61) 2026-5336 \\ Correio eletrônico: livraria@ipea.gov.br
}



Composto em adobe garamond pro 12/16 (texto) Frutiger 67 bold condensed (títulos, gráficos e tabelas) Brasilia-DF 



\section{Missão do Ipea}

Aprimorar as políticas públicas essenciais ao desenvolvimento brasileiro por meio da produção e disseminação de conhecimentos e da assessoria ao Estado nas suas decisões estratégicas.

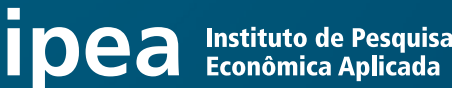 \\ MINISTÉRIO DA \\ ECONOMIA

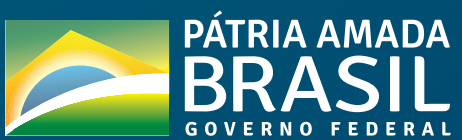

